\title{
Community Development AgReEMEnT
}

\section{Model Regulations \& ExAMPLE GUidelineS}

\author{
World Bank Group \\ Contract Number 7154096 \\ - FINAL REPORT -
}

Submitted by:

James M. Otto

Vendor \# 95962

June 2010 


\section{Community Development Agreement Model Regulations and Example Guidelines}

\section{Table of Contents}

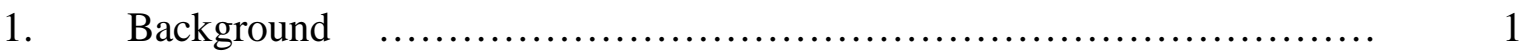

2. Phase 1. Technical Development of Model CDA Regulations .............. 2

3. Phase 2. Stakeholder Engagement ................................. 3

Annex 1. Annotated Community Development Agreement Model Regulations ..... 5

Annex 2. Community Development Agreement Model Regulations ........... 32

Annex 3. $\quad$ Example of Community Development Agreement Guidelines ........ 58

Annex 4. Phase 1 Consultation (Meetings and Persons Met) ................ 75

Annex 5. Technical Review Workshop Attendees ........................ 77

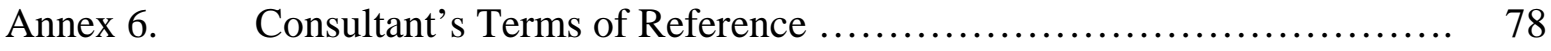

Annex 7. About the Consultant ......................................... 81

\section{Abbreviations}

CDA

COCPO

ICMM

IFC

WBG
Community Development Agreement

Oil, Gas and Mining Policy and Operations Unit (World Bank)

International Council on Mining and Metals

International Finance Corporation

World Bank Group 
Community Development Agreement Model Regulations and Example Guidelines

Prepared for the World Bank by James Otto

\section{BACKGROUND}

Mines have the potential to impact communities and such impacts can be both positive and negative. Historically, mines have played an important role in impacted communities but that role usually ended with the closure of the mine. More recently, there is a strong interest by governments, communities and mining companies in the sustained development of mine impacted communities. Additionally, communities have become more vocal and self-empowered with regard to their relationship with mining companies, and their expectations for immediate and future benefits have increased. This move toward self-empowerment is often assisted by international or national non-governmental organizations. Increasingly, communities may actively resist new and ongoing mining projects unless they are satisfied that they will sufficiently benefit from such projects. In addition to impact mitigation a new focus is emerging on community development.

Mining companies are concerned about the need and means by which to obtain and maintain their "social licence to operate" including local community support. Various industry-wide initiatives have examined ways by which such support can be proactively obtained and retained including approaches to help define a company's role in community development. These initiatives have resulted in a variety of voluntary approaches. Each company approaches its impacted communities in a different way and may chose different approaches in different nations and communities. Some mining companies make community development a strong priority, others do not.

The World Bank Group (WBG) has a role to play in mining-led development at both the national and community level. At the national level, client countries often focus their requests for WBG assistance on matters such as investment promotion, and administrative, legal and fiscal reform support. Increasingly, there is interest in assistance that addresses the development of mine impacted communities, and the WBG has been involved in developing practical voluntary approaches that can be adopted by industry, government and other stakeholders. Examples of this involvement include, but are not limited to, the Equator Principles (lending principles) and more recently, the "Community Development Toolkit" (jointly developed and published by the World Bank Group and the International Council on Mining and Metals ${ }^{1}$ ). This report provides another tool that may be useful to aid in the development of mine-impacted communitiesmodel community development agreement regulations and example guidelines derived from the model regulations.

Community development agreements (CDAs) are increasingly being used by mining companies as a means to better define their relationships and obligations with impacted communities. They can play a valuable role in managing the expectations of a broad range of stakeholders including, for example, the mining company, the impacted communities, local and national government, and non-governmental organizations. Legislative requirements for CDAs are still rare but increasingly governments are considering legislation that would define when such an agreement is required and what subject matter such an agreement can address.

1 Community Development Toolkit, ESMAP Formal Report Series, Report No. 310/05, October 2005. 
The purpose of this report is to provide draft model community development agreement regulations suitable for adoption into legislation or which can be modified for use as guidelines. It is not the intent of this report to suggest that every nation should adopt the model legislation, rather the model legislation is simply another tool that governments can consider as part, or not, of their development strategy. In many nations, the promulgation of regulations is easier than introducing a new or amended mining law, and thus, model regulations were drafted rather than model mining law provisions. However, the model regulations can be amended for inclusion in a mining law. This report also contains an example of how the model CDA regulations can be modified into CDA guidelines. For nations which prefer not to legislate CDA requirements, guidelines can be an attractive alternative. Governments use guidelines in different ways. In some nations, guidelines merely provide information that may be used on a voluntary basis (as illustrated in the example guidelines in Annex 3). In other nations, there may be a requirement in the law that the affected party must accomplish some obligation in accordance with strict administrative guidelines (similar to regulations, but bypassing the necessity to bring regulations into effect through the prescribing power of a Minister/Cabinet/Council or a legislative process).

The limitations of model legislation cannot be overstated. The policies, needs and priorities of governments vary widely and an approach that is well-suited for one country may be unsuitable for another. Likewise, legal drafting styles as well as legal frameworks vary considerably from nation to nation. The model regulations have been drafted in a style that should be amenable to modification into a wide variety of legal systems, and it is expected that governments who want to make use of the model regulations will redraft them so as to meet their own particular development, regulatory and stylistic requirements. It is possible that the model regulations/guidelines may also prove useful for regional regulatory harmonization efforts.

This report is the product of a phased project approach. Phase 1 was designed to prepare a draft set of CDA regulations in consultation with and benefiting from technical experts. Phase 2, of which this report is a part, was intended to obtain feedback from a broad spectrum of stakeholders including governments, private sector, non-governmental organizations, civil society and development experts.

\section{Phase 1. Technical Development of Model CDA Regulations}

In Phase 1A, B. Bocoum, Senior Mining Specialist, and K. Svensson, Operations Officer, World Bank Oil, Gas and Mining Policy and Operations Unit (COCPO), arranged for the Consultant to talk with WBG staff involved with mining related projects, with selected non-governmental organization experts and industry. The purpose of these talks was to identify examples of best practice approaches, identify past and on-going country and WBG work that might be pertinent to the effort, locate resource materials including toolkits and CDAs, and, in particular, to gain insights from experienced experts (see Annex 4 for a list of meetings and persons met). At the conclusion of Phase 1A, a preliminary outline of regulations was prepared by the Consultant and reviewed by COCPO. 
Community Development Agreement Model Regulations and Example Guidelines

Prepared for the World Bank by James Otto

During Phase 1B, based on knowledge gained during Phase 1A and on the preliminary regulations outline, the Consultant prepared an initial report containing draft model regulations. ${ }^{2}$ The model regulations were prepared taking into consideration an examination of CDAs from geographically diverse nations. Additionally, concepts contained in various WBG toolkits that pertain to community development were considered, along with the advice offered by the experts listed in Annex 4.

In Phase 1C, a Technical Review Workshop was held. Staff from various departments of the WBG, mining industry representatives, social scientists and civil society organizations met at WBG headquarters to review and comment on the phase 1B draft regulations (for attendance, see Annex 5). Based on Phase 1C comments and suggestions, the Consultant revised the draft CDA model regulations, in preparation for the Phase 2 stakeholder engagement process.

\section{Phase 2. Stakeholder Engagement}

In order to obtain feedback from a broad spectrum of stakeholders (governments, private sector, non-governmental organizations, civil society, development experts) workshops and meetings were held in the first half of 2010.

Two well-attended open-forum sessions were held at the INDABA (Cape Town, South Africa) and PDAC (Toronto, Canada) mining conferences. Useful suggestions were offered by attendees to improve the CDA building block approach used by the Consultant. At these sessions, some industry representatives indicated that CDA guidelines might be useful as an alternative to model CDA regulations, and others preferred a wholly unregulated CDA environment with neither government regulations nor guidelines. Recommendations by social scientists who work at the interface between communities and mining companies to manage the processes which might lead to a CDA or other arrangement were especially useful in identifying ways in which the draft model regulations might be improved. Feedback from representatives of various governments indicated strong support for the CDA concept of community level development. A common concern among many participants was the respective community level role of government and the mining companies, and how these roles might change over the mining cycle of exploration, development, exploitation, closure, and post-closure.

The World Bank CDA team also met with a group of Canadian First Nation Chiefs, representatives and experts. Canadian First Nations have negotiated over 150 "impact and benefits" agreements (a form of CDA) over the last several decades. Of particular importance from this consultation were the lessons learned by First Nations in implementation of their respective agreements. Key issues for this group of stakeholders included: the need for integrated land use planning, the training of community persons in specialized skills (capacity building), the importance of recognizing community cultural values and their integration into the community/company relationship, free prior informed consent, generating future sustained income, local procurement and enforceability of their agreements.

2 James Otto, "Community Development Agreement Model Regulations," prepared for the World Bank Group under contract 7151320; Washington DC: June 20, 2009. 
A consultation workshop was also held with invited experts from civil society coming from Canada, Kazakhstan, Liberia, Senegal and the USA. Among the most important issues for this group were transparency, integrated planning with government departments, the process and the ability of communities to effectively participate in the CDA process and enforceability.

A final stakeholder workshop was held at WBG headquarters. Participants included government representatives from Ghana, Laos, Nigeria, Papua New Guinea, Peru; civil society representatives from the Canada (First Nations tribes); community development experts; mineral industry representatives; and WBG staff. Workshop participants contributed a wide range of comments including concepts such as an agreed development program plan complete with milestones and expenditure schedule, revenue smoothing, community capacity enhancement, participation by youth representatives, agreement ratification, financial support for community participation in the CDA negotiation process and recognition of traditional value systems.

This final report was prepared taking into consideration the suggestions obtained through the Phase 2 stakeholder engagement process. In addition to the three introductory sections, this report consists of annexes containing: an annotated version of the model CDA regulations; an un-annotated set of the model CDA regulations; example of how the CDA regulations can be modified to a guideline format; a list of Phase 1A meetings and persons met by the Consultant; a list of persons and organizations attending the Phase 1C Technical Review Workshop; the Consultant's terms of reference (Phase 1 and Phase 2) and background information on the Consultant.

There is no single best practice approach that can address every issue arising from the complex relationship between unique communities, miners and governments. The objective of the following model regulations and derived guidelines is to provide examples that may be useful in ongoing efforts to optimize the potential for mines to effectively operate in harmony with and to the benefit of communities affected by their operations.

While preparation of the model regulations (and example guidelines) in this report was commissioned by the WBG, they do not constitute the opinion or position of the WBG and are solely attributable to the Consultant. 
Community Development Agreement Model Regulations and Example Guidelines

Prepared for the World Bank by James Otto

\section{ANNEX 1. Annotated Community Development Agreement Model Regulations}

A special challenge in drafting the model CDA regulations was to define the respective roles of the mining right holder, the impacted communities, local government, central government and non-governmental organizations. Every nation, mine and community is different and it is recognized that substantial modifications may be needed to fit the "model" regulations to a particular government's needs and policies.

The approach taken in the model regulations is to allow the mining rights holder and communities to independently negotiate CDAs. The CDA negotiation process is not defined in the regulations in recognition that each project will be substantially unique. Who comprises a community that qualifies for a CDA is defined in part by the regulations, and a list of qualified communities is submitted by the mining rights holder to the Minister (or other designated responsible government authority), who may approve or amend the list based on consultations with local government. A community may independently apply to be designated a qualified community. Any negotiated CDA is submitted to the Minister (or other designated responsible government authority) who shall approve it provided that all regulatory requirements are met. The central government is not a party to the agreement, but local authorities can be. The mining rights holder must submit periodic reports to the central government for each CDA. All CDAs and periodic reports are public information. The mining rights holder is required to expend a percentage of its revenues on community development activities, and such expenditures must be reported annually. Failure to comply with key regulations can trigger a fine, and some infractions may lead to suspension of the mining right. Non-governmental organizations may be involved in the implementation of individual CDAs at the discretion of the mining rights holder and the community. Regulations also mandate that CDAs are to be negotiated taking into consideration government's local and regional development plans.

List of regulations:

1. Citation

2. Regulations supplement [Mining Act / Code Minier]

3. Object

4. Interpretation

5. General obligation to promote community development

6. Where community development agreement is required

7. Content of community development agreement

8. Capacity of community to negotiate

9. Approval of community development agreement

10. Community development agreements to compliment other agreements and development plans

11. One agreement may include more than one qualified community

12. Replacement of multiple agreements with single agreement

13. New community members

14. New communities 
Community Development Agreement Model Regulations and Example Guidelines

Prepared for the World Bank by James Otto

15. Only one agreement required where the community is the same

16. Minimum expenditure requirement

17. Ministry to respect community development agreements

18. Reporting requirements

19. Community development agreements and periodic reports available to the public

20. Transfer

21. Penalties

22. Suspension of mining rights

23. Regulations to apply to preexisting mining rights

24. Regulations to prevail if inconsistent with mining agreement

Schedule 1. Fees

Schedule 2. Community Development Agreement Report Form

Schedule 3. Community Development Expenditure Annual Report Form

Citation, commencement

Regulations supplement [Mining Act / Code Minier]
1. These regulations may be cited as the [Mining (Community Development Agreement)] Regulations, $20[X X]$ and shall come into force on [date].

Comment: while drafted here as regulations, the content of the model regulations can be modified to be used as articles in a mining code, standalone law, or as guidelines.

2. These regulations are supplemental to the [Mining Act/Code Minier] and the [General Mining Regulations] and are to be observed in conjunction therewith as far as practicable, but should at any time any inconsistency occur between a provision in these regulations and provisions in the [General Mining Regulations], the [General Mining Regulations] shall prevail.

Comment: another approach would be to simply amend the general mining regulations incorporating the CDA regulations. 
Community Development Agreement Model Regulations and Example Guidelines

Prepared for the World Bank by James Otto

\section{Object}

Interpretation
3. The objects of these regulations are:

(a) to enhance the sustainable social, cultural and economic well-being of communities impacted by mining operations;

(b) to define when community development agreements are required and to provide a framework for such agreements;

(c) to ensure accountability and transparency in mining related community development.

Comment: many nations follow a drafting style that allows the object of the regulations to be part of the regulations, others do not. In the later case, this regulation can be deleted.

4. In these regulations, except where otherwise expressly provided -

"community development agreement" means a community development agreement approved pursuant to these regulations;

"general mining regulations" means [citation for the primary regulations made under the mining act/code minier];

"[Local Authority]" means [insert appropriate government entity]; Comment: the intent here is to identify the level of government that is primarily concerned with local community governance and planning tasks.

"[Mining Act/Code Minier]" means [insert citation here for the mining act/code minier];

"mining right" means [name of authorization(s) that grants large scale mining rights under the mining law/code minier such as large scale mining licence, mining lease, mining concession, ...];

Comment: the intent here is to identify the name of the appropriate legal authorization(s) to which the CDA requirements apply. Many nations have several forms of mining authorization (artisanal permit, small-scale mining licence, mining lease ...). Any type of authorization that the regulations should apply to should be named here.

"[Minister, Ministry, Director of Mines]" means the [Minister, Ministry, Director of Mines] for the time being charged with the primary responsibility for mines and mining;

Comment: national legal drafting style guidelines may specify 
whether the persons title (Minister) or agency (Ministry) is to be used. The designated authority can be any governmental person/entity that is responsible in the circumstances. In many nations, regulations designate the responsible Minister as having the lead role, but such role could also reside with a technocrat such as a director of mines, chief inspector of mines, or other officer that has approving or enforcement powers under the mining act.

Alternative 1.

"qualified community" means a community that has the potential to be significantly negatively or positively impacted by mining operations;

Comment: the intent here is to identify what constitutes a qualified community for the purpose of CDAs. Alternative 1 is broadly worded and allows for broad interpretation. Any number of communities can be qualified communities.

Alternative 2.

"qualified community" means a community that has been specifically identified in an [environmental and social impact assessment] required under the [Environmental Protection Act] as having the potential to be significantly negatively or positively impacted by mining operations;

Alternative 3.

"qualified community" means the single community of persons mutually agreed by the mining right holder and the [local authority]: Provided, if the mining right holder and [local authority] cannot agree on which community is the host community, the mining right holder may notify the [Minister, Director of Mines ] requesting clarification, and the [Minister, Director of Mines ] shall notify the mining right holder, specifying which community is the qualified community;

Comment: Alternative 3 is much narrower than the other alternatives which allow for multiple CDAs. The strength of this option is that it allows all CDA efforts to be focused on a single community perhaps resulting in a "center for development" (a center for development can act as a central resource for neighboring communities, by providing centralized services). If CDA resources are spread among several or many communities, perhaps no one community benefits enough to achieve a significantly strengthened development potential. The weakness of this approach is that communities not selected may harbor resentment and ill-will. While this approach may have high development potential, it also may pose political challenges in nonautocratic societies.

Alternative 4. 
General obligation to promote community development "qualified community" means a community of persons residing within [text (number)] kilometers of any boundary defining the mining right area;

Comment: Alternative 4 is a simplistic approach, but may have potential in high population density areas, or conversely, where populations are located far away from mining areas.

"ratified community development agreement" means a community development agreement that has been approved by the respective community according to such process and in such manner as is customary for such community to make decisions on matters affecting the community as a whole.

Comment: Communities have different ways and means of organization and decision-making even within a small geographical region. The definition is worded to address a wide range of possibilities.

"sub-community" means a group of persons classified as a subcommunity for the purposes of these regulations by the [Minister, Ministry, Director of Mines], in consultation with the [Local Authority], because their number is too small to comprise a qualified community, but who are for the purposes of these regulations deemed part of a qualified community.

Comment: the intent here is to identify what constitutes a subcommunity for the purpose of CDAs. For example, there may be many clans that comprise a tribe. Should each clan be entitled to a CDA or only the tribe? The regulations that address CDA content direct that the concerns of sub-communities be part of the CDA.

5. The holder of a mining right shall assist in the development of communities affected by its operations to promote sustainable development, enhance the general welfare and the quality of life of the inhabitants, and shall recognize and respect the rights, customs, traditions and religion of local communities.

Comment: this is a general obligation that applies whether or not a CDA is required.

6.

\section{(1)}

Comment: if a mine is small, its impact potential, either positive or negative, on communities can be small or negligible. Thus, this regulation is used to define what scale of mine requires CDAs. The cutoff can be based on throughput, number of workers, sales, or any other basis. Where a mining law provides a special licence for larger scale operations, the scale requirement can be deleted and instead "mining right" can be defined to be that type of licence. Another way to define 
qualified community is to link the need for a CDA to the requirement to prepare an environmental and social impact assessment, or as the result of such a study. Several alternatives examples are provided below.

Alternative 1. The holder of a mining right is required to have and implement ratified community development agreements with all qualified communities if its approved mining operation will or does exceed any of the following limits:

(a) in the case of extraction of minerals from primarily alluvial deposits, where annual throughput is more than $[x$ cubic metres $]$ per year; or

(b) in the case of underground mining operations, where annual combined run-of-mine ore and waste production is more than [ $x$ tonnes] per year (waste material not exiting mine mouth to be excluded); or

(c) in the case of open-cast mining operations extracting minerals from primarily non-alluvial deposits, where annual combined run-of-mine ore, rock, waste and overburden production is more than $[x$ tonnes $]$ per year; or

(d) where the holder of a mining right employs or contracts or will employ or contract more than $[x]$ employees or workers at the mine site on a typical working day after the commencement of mineral production (including all shifts).

Alternative 2. The holder of a mining right is required to have and implement ratified community development agreements with all qualified communities.

Alternative 3. Where the holder of a mining right is required to complete and submit an [environmental and social impact assessment] under any law then in force and the assessment finds that communities may be significantly negatively or positively impacted by mining operations, the holder of the mining right is required to have and implement ratified community development agreements with all qualified communities.

(2) The holder of a mining right shall-

(a) before commencing mine development (or where 
the mining right came into force before the publication date of these regulations and mine development has already commenced or has been completed, within one hundred and eighty (180) calendar days of such publication date), and

(b) at (5) five year intervals after the year in which mining commences (or where the mining right came into force before the publication date of these regulations and mining commenced before such publication date, at (5) year intervals from the date on which mining commenced),

identify all qualified communities and submit a draft list of such qualified communities to the [Minister, Ministry, Director of Mines], but if there are no qualified communities, this regulation does not apply.

Comment: A challenge for companies is to determine what constitutes a community for the purpose of CDAs. This regulation puts the initial burden on the company to identify qualified communities. Mines can operate for many years and some communities may vanish and others appear. Thus, there is a need from time to time to examine who constitutes a qualified community. The timing requirement takes into account that, often, the holder of a mining right is not the same entity as the party that held a prior exploration right. In practice, it is possible (and laudable) that substantial consultations may have taken place earlier than the required trigger time in this regulation. Such consultations are beyond the scope of this regulation.

(3) The [Minister, Ministry, Director of Mines], in consultation with the [Local Authority], shall within sixty (60) calendar days of receiving a submission under sub-regulation (2) approve or amend the draft qualified community list, and where it amends the list it shall notify the mining right holder explaining the reasons for such modification.

Comment: This sub-regulation provides the government with the authority to add or delete communities from the list proposed by the company. These regulations come into force under the mining law so the appropriate minister is the minister for mines. However, government expertise on local communities most likely resides with local government so the minister is required to consult with the local authority.

(4) Any community of persons may at any time notify the [Minister, Ministry, Director of Mines] that it believes it is a qualified community.

Comment: This sub-regulation allows a community that feels it has been 
overlooked, or perhaps considered by the company as part of another community, to apply to be classified as a qualified community.

(5) The [Minister, Ministry, Director of Mines], in consultation with the [Local Authority], shall within sixty (60) calendar days of receiving a submission under sub-regulation (4) notify both the community of persons and the holder of the mining right whether the community of persons is a qualified community, and if it is not a qualified community, explain the reasons why not and whether it is to be considered a sub-community of a qualified community.

(6) The [Minister, Ministry, Director of Mines], in consultation with the [Local Authority], may reject the request submitted under subregulation (4) as a non-qualified community where that community of persons -

(a) does not meet the definition of a qualified community; or

(b) because of its small size is considered a subcommunity of a qualified community.

Comment: In almost all cases, prior exploration will have been done before a mining right is obtained, and such exploration may have been done by the same company that is awarded the mining right, or as is often the case, by another company. During the exploration stage, the exploring company may have entered into "early stage agreements" with communities. The regulation below does not require that such early stage agreements be mandatorily made part of a mining right holder's CDA-that would be a decision for the mining right holder and the community to decide at the time the CDA is negotiated. An alternative is to require that early stage agreements be honored in a CDA. Careful consideration should be given to any such later requirement because the explorer may not be the miner, and what the explorer "promised" may be unrealistic or inappropriate for execution by the miner and community.

Content of community development agreement
7. -

(1) Subject to sub-regulation 7(3), the holder of a mining right who is required to have ratified community development agreements shall negotiate with each qualified community the terms of a community development agreement, and such agreements shall include at least the following provisions:

(a) the person, persons, board, committee, foundation, trust, forum, body or other entity which shall manage the agreement; 
Comment: An examination of existing CDAs revealed that each agreement had some sort of organizational structure for implementing the agreement. The wording here is broad to allow flexibility as may fit unique circumstances.

(b) the person or body that represents the qualified community for the purposes of the agreement;

Comment: It is not always clear who represents a community. This may be especially a problem if there are a number of sub-communities, or widely dispersed individual families or clans. Thus, the agreement will need to clearly define who represents the community. This determination may be a lengthy process as it may entail the need to develop linkages between community members that currently do not exist.

(c) the means by which a registry of persons comprising the community will be developed, maintained and updated;

(d) the means by which members of a qualified community will participate in the community's agreement related decision-making processes;

(e) the means by which the interests of women, youth, minority and marginalized groups and sub-communities of the qualified community will be represented in the community's agreement related decision-making processes and implementation;

(f) the goals and objectives of the community development agreement;

(g) a community development program plan which shall include at least the following::

(i) objectives,

(ii) milestones;

(iii) implementation timetable;

(iv) schedule of anticipated expenditures; 
(v) metrics by which to measure progress;

(vi) periodic reporting including actual expenditures;

(vii) how the plan works in coordination with government plans, services, infrastructure and activities provided to or affecting the community;

(viii) how the provision of any service provided by the mining right holder to the community will be terminated or transferred to the community, government or other entity;

(ix)how and when the plan will be periodically updated;

(x) how the plan and amendments to the plan will be ratified by the community; and

(xi).such other content as may be mutually agreed by the community and the mining right holder.

(h) the roles and obligations of the holder of the mining right to the qualified community, which may or may not be part the development program plan required under sub-regulation $7(1)(\mathrm{g})$, including but not limited to:

(i) undertakings with respect to the social and economic contributions that the project will make to the sustainability of the community;

(ii) assistance in creating self-sustaining, income-generating activities, such as but not limited to, production of goods and services needed by the mine and the community;

(iii)consultation with the community in the planning of mine closure and post-closure measures that seek to prepare the community for the eventual closure of the mining operations; 
(i) the roles and obligations of the qualified community to the holder of the mining right;

(j) the roles and obligations of the [Local Authority], if it is a party to the community development agreement or otherwise so chooses to be obligated;

(k) the means by which the community development agreement shall be reviewed by the holder of the mining right and qualified community every five (5) calendar years, and the commitment to be bound by the current agreement in the event that any modifications to the agreement sought by one party cannot be mutually agreed with the other party;

Comment: This paragraph allows the CDA to evolve as situations change.

(1) the consultative and monitoring frameworks between the holder of the mining right and the qualified community, and the means by which the community may participate in the planning, implementation, management, measurement (including indicators) and monitoring of activities carried out under the agreement;

(m) the language(s) to be used in the preparation of reports, plans, and other written matters required under the agreement;

(n) the means by which any funds made available under the agreement are to be disbursed, for what purposes they may be disbursed, what accounts must be kept and by whom, and reporting and auditing requirements;

(o) the mechanisms whereby the qualified community, and sub-communities and members of the qualified community may lodge a grievance with the mining right holder;

(p) the mechanisms whereby the mining right holder may lodge a grievance with the qualified 
community;

(q) a statement to the effect that both the holder of the mining right and qualified community agree that any dispute regarding the agreement shall in the first instance be resolved by consultation between the holder and the qualified community representative(s);

(r) the dispute resolution mechanism to be used when consultation between the holder and the qualified community representative(s) fails;

(s) the process by which the agreement may be modified;

(t) severability of articles;

(u) the applicable law, which shall be the law of [name of country];

(v) reasons and procedure for declaring force majeure;

(w) duration of the agreement;

(x) termination of the agreement;

(y) assignment of the agreement or any right or obligation there under;

(z) transfer of all community development agreement rights and obligations to any party to whom the mining right holder transfers its mining right;

(aa) how notifications to respective parties shall be done;

(bb) location where the agreement may be accessed by members of the community;

(cc) the agreement signatories, which may for the qualified community be the representatives of the community, representatives of subcommunities comprising the community, 
community members or any combination thereof, non-governmental organizations, and others as the need requires.

Comment: The community signatories to a CDA are not always readily identifiable and this regulation provides substantial flexibility. In some instances, for example, it may be useful to have every family-head sign and in other situations, just the town mayor.

(2) Subject to sub-regulation 7(3), a community development agreement shall take into account the unique circumstances of the holder of the mining right and qualified community, and the issues to be addressed in the agreement and development program plan may include all or some or none of the following: -

(a) role of local government;

(b) educational scholarship, apprenticeship, technical training and employment opportunities for the people of the community;

(c) employment quota or percentage allocation for sub-communities;

(d) financial or other forms of contributory support for infrastructural development and maintenance such as education, health or other community services, roads, water and power;

(e) assistance with the creation, development and support to small-scale and micro enterprises;

(f) special programs which benefit women;

(g) special programs which benefit youth;

(h) special programs which benefit sub-communities within the qualified community;

(i) agricultural product marketing;

(j) protection of natural resources;

(k) support for cultural heritage and sports;

(1) treatment of cultural and sacred sites; 
(m) treatment of ecological systems, including restoration and enhancement, for traditional activities such as hunting and gathering;

(n) language training to further employment prospects;

(o) how cultural values will be respected;

(p) cross-cultural training requirements;

(q) malaria, AIDs and drug dependency prevention and intervention;

(r) land access;

(s) the assumption of specified obligations of the mining right holder by the qualified community, sub-communities and/or government on an evolving basis and/or upon termination of the agreement;

(t) methods and procedures of environment and socio-economic management, and local governance enhancement;

(u) requirements with regard to third parties such as the mining right holder's contractors and suppliers;

(v) the involvement of non-governmental organizations; and

(w) other matters as may be agreed.

Comment: This list of "optional" provisions is based on a review of CDAs from jurisdictions in Africa, Asia, North America and the Pacific. The last listed provision, (v), provides flexibility for additional provisions. While this sub-regulation is not absolutely necessary, because the items are at the option of the parties, it was included to provide a framework for negotiations between the mining right holder and the qualified community. The list could be shortened to exclude items that are not specifically related to mining such as $d, g, l, p, q$ and $r$. Under ideal circumstances some of these items ought to be the sole responsibility of government but many existing agreements do address 
these subjects because government has not effectively fulfilled its role. It is anticipated that governments when drafting CDA regulations/guidelines will modify this list accordingly.

(3) Goals, objectives, obligations and activities specified in a community development agreement should aim to achieve sustained community development which -

(a) lasts from generation to generation;

(b) is based on the actual needs of the community;

(c) is maintainable within available income;

(d) is well planned, monitored and evaluated;

(e) has long term benefits;

(f) prepares the community for closure of the mine;

(g) compliments but does not replace governmentled development and services;

(h) is in accord and compliments local and regional government development plans;

recognizes and incorporates traditional knowledge.

Comment: This sub-regulation provides the guiding principles for CDAs and can be incorporated in part or in whole in a CDA's preamble.

(4) The [Local Authority] may be but is not required to be a party to a community development agreement.

Comment: Many existing CDAs do not include local government as a party, but in some circumstances, this may be useful. In particular, where a CDA obliges the mining rights holder to provide a service, the CDA can describe how this provision of service will eventually be done by local government so that at mine closure the service can be continued. A regulation is not provided whereby the central government may be a party to a CDA. Central government's role is restricted to that of the regulator.

(5) A community development agreement may not address any of the following matters - 
(a) the imposition of any additional rent, fee, or tax for the benefit of the qualified community that is not set out by law;

(b) the provision of any passenger car, small truck, or four-by-four vehicle to any individual or single family unit of the qualified community or to the qualified community, other than a specialized purpose vehicle such as an ambulance, fire engine, water truck, or bus;

(c) the provision of any monetary amount, service, good, or facility for the sole benefit of an individual or single family unit; or

(d) any matter that is illegal under any law then in force.

Comment: Experience has shown that CDAs can be used and manipulated to promote the interests of a few elite individuals or families within the community. These provisions seek to reduce activities which would not be in the interest of the whole community.

(6) A community development agreement shall be in [official language] but where a substantial proportion of the community members are not fluent in [official language], the mining right holder party to such agreement shall make available to representatives of the qualified community translated unofficial copies in the local language or dialect.

Capacity of community to negotiate

\footnotetext{
Approval of community development agreement
}

8. Where a qualified community lacks the capacity to effectively negotiate a community development agreement, the mining right holder shall assist to build that capacity including the provision of such funds to the community for capacity-building and preparation as are reasonable in the circumstances.

Comment: Many communities have little or no experience with the mining sequence and may not be able to effectively represent the community's interest in negotiating a community development agreement. Capacity building as part of the process may be essential. Capacity building can involve, for example, the hiring of specialists by the community of independent experts to assist the community in understanding the implication of the project and to represent their interests.

9 .

(1) A community development agreement or revised community development agreement agreed and signed by the authorized renresentatives of a holder of a minino rioht and a cualified communitv 
representatives of a holder of a mining right and a qualified community shall be submitted for approval to the [Minister, Ministry, Director of Mines] who shall, if the agreement meets the requirements set out in regulation 7, approve such agreement within forty-five (45) calendar days of it being submitted.

Comment: This regulatory oversight insures that CDAs contain all mandatory content and establishes a key role of the Minister (or other government entity or person) responsible for the regulations.

(2) The holder of a mining right submitting a community development agreement for approval shall pay the non-refundable processing fee specified in Schedule 1.

Comment: It is suggested that the fee be more than nominal. The government may expend substantial money in verifying the content of a proposed CDA, and the fee should be enough to offset all such costs, even if the fee flows to the treasury rather than to the implementing department.

(3) A community development agreement shall come into force upon its approval by the [Minister, Ministry, Director of Mines].

(4) If a community development agreement or revised community development agreement is not approved, the [Minister, Ministry, Director of Mines] shall notify both the holder of mining right and the qualified community representative, and such notices shall contain the specific reasons for denial and the means or directions by which such reasons may be corrected.

(5) The [Minister, Ministry, Director of Mines] shall cause, within thirty (30) calendar days from the date on which a notification is made under paragraph (4) of this sub-regulation, a copy of the notification to be put on open file at the [Mining Cadastre Office, Department of Mines, Ministry] for access by the public.

(6) The holder of the mining right and the qualified community representatives may submit any number of revised community development agreements and such submissions do not require the payment of any additional processing fee.

(7) If the holder of the mining right and a qualified community are unable to agree on the terms of a community development agreement, they may by mutual consent seek to resolve their differences through mediation. 
(8) If the holder of the mining right and a qualified community fail after reasonable good faith attempts to conclude a community development agreement by the time the mining right holder is ready to commence development work on the mining rights area, the holder or the qualified community may refer the matter, jointly or individually, by notification to the [Minister, Ministry, Director of Mines] for resolution, and the decision of the [Minister, Ministry, Director of Mines], in consultation with the [Local Authority], thereon shall be final.

Comment: This is a key sub-regulation. It allows the Minister or other designated person or entity responsible for the regulations to in effect impose a CDA where a community or mining right holder cannot agree on essential terms. In most nations, minerals belong to the state or to the people of the state as a whole, and for this reason, most nations consider minerals development a national or state, and not community, decision. If the nation follows the "prior free informed consent" philosophy this subregulation will require modification removing this ministerial power.

(9) A notification under sub-regulation (8) from either or both parties shall include the draft community development agreement proposed by the party, description of the efforts to negotiate an agreement or revised agreement, issues that have been agreed, issues which have not been agreed, and proposals to resolve issues, and the [Minister, Ministry, Director Mines] shall determine the matter within sixty (60) calendar days of such notification.

(10) The [Minister, Ministry, Director of Mines] shall within thirty (30) calendar days from the date on which a community development agreement is approved cause a copy of the agreement or revised agreement to be put on open file at the [Mining Cadastre Office, Department of Mines, Ministry].

Comment: This sub-regulation provides for maximum transparency and accountability.

Community development agreements to compliment other agreements and development plans
10. The holder of a mining right that is required to enter into a community development agreement with a qualified community shall take into consideration --

(a) any community development agreements it has with other qualified communities so that such agreements compliment one another to achieve synergistic development across the communities;

(b) any existing community development agreements entered into by that qualified 
community with other holders of mining rights so that its community development agreement compliments such existing agreements, and such mining right holder may, but is not required to, become a party to any such existing agreements;

(c) any government local or regional development plans or schemes so that the agreement is in harmony with and compliments such plans or schemes; and

(d) any government services provided or which will be provided to a qualified community so as not to displace that service.

One agreement may include more than one qualified community

Replacement of multiple agreements with single agreement

New community members

New communities
Comment: There may be a variety of parties who if they coordinate their efforts can achieve more optimal development than if each works independently.

11. Where the holder of a mining right is required to enter into ratified community development agreements with more than one qualified community, the holder may enter into one or several community development agreements that include multiple qualified communities, but the holder must have a separate community development agreement with a qualified community that does not want to be part of a multiple party agreement.

12. Where the holder of a mining right has entered into more than one ratified community development agreement and the parties to two or more of these agreements now want to replace their agreements with a single community development agreement, such new agreement shall be submitted for approval under regulation 9 .

13. Any person or group of persons not appearing in the registry of persons constituting a qualified community may with the approval of the body responsible for the management of a CDA be added to such registry at any time and shall then be considered a member of that qualified community.

14. Any community of persons that is not approved and listed by the [Minister, Ministry, Director of Mines] as a qualified community

(a) on the date that a mining right holder commenced mining operations (if after the publication date of these regulations), or

(b) one hundred and eighty calendar days (180) after 
the publication date of these regulations (if mining operations commenced before such publication date)

Only one agreement required where the community is the same

\section{Minimum expenditure requirement}

is not a qualified community and a community development agreement with such a community shall be at the option of the mining right holder.

Comment: The opening of a mine can result in a migration of persons to the area and the establishment of "squatter camps." A CDA requirement could act as an additional incentive for such migration absent a regulation such as this one. However, realizing that a CDA might be useful in the future, an option is left open to the mining rights holder.

15. Where a person is the holder of more than one mining right and these regulations would otherwise require the holder to enter into a ratified community development agreement with the same community under each mining right, only a single community development agreement and [ semi-annual ] community development reports are required with regard to that community.

16.

(1) The holder of a mining right who has entered into one or more ratified community development agreements shall expend

(i) in the first calendar year following the commencement of mineral sales, no less than [ text ] percent ([ number $] \%$ ) of the gross revenue amount earned pursuant to that right from mineral sales in the previous calendar year;

(ii) in the second calendar year following the commencement of mineral sales, no less than [ text ] percent ([ number ] \%) of the gross revenue amount earned pursuant to that right from mineral sales in the previous two calendar years divided by two (2);

(iii) in the third calendar year following the commencement of mineral sales and in each subsequent calendar year no less than [ text ] percent ([ number ] \%) of the gross revenue amount earned pursuant to that right from mineral sales in the previous three calendar years divided by three (3)

to implement the agreement(s) or otherwise promote community development.

Comment: This sub-regulation provides clear guidance on the fiscal amount that must be expended. By knowing roughly the amount 
mandated for development (the feasibility study will provide an estimate of revenues) it will make it easier to negotiate CDAs. This amount can be spent on CDA activities plus other activities related to community development but which are not part of a project's CDAs. The averaging method is suggested so as to provide revenue smoothing.

(2) If during any calendar year, the holder of a mining right expends an amount on community development in excess of the annual minimum expenditure amount required, such excess amount may be applied to satisfy up to [ text ] percent ([ number ] \%) of its expenditure requirement in the next calendar year.

(3) If during any calendar year during the term of the mining right the holder thereof does not expend an amount at least equal to the minimum annual expenditure amount required under sub-regulation $16(1)$, including any excess amount carried forward from the previous calendar year pursuant to sub-regulation 16(2), the mining right shall be subject to suspension.

Comment: This sub-regulation is intended to foster compliance.

(4) The value of community development related work, if the expenditures are reasonable, documented in sufficient detail to establish their authenticity to the satisfaction of the [Director of the Mining Cadastre, Director of Mines, Minister, Ministry], and directly related to the objectives of one or more ratified community development agreements includes:

Comment: This sub-regulation restricts what can be counted as community development for the purposes of minimum expenditure requirements. The list reflects the types of activities recommended in WBG community development related toolkits as well as other useful work.

(a) at full cost, whether incurred directly by the mining right holder or indirectly through payments to a contractor, community trust, community foundation or other legal entity,

(i) work or funds irrevocably committed to fulfill any obligation of the mining right holder specified in a ratified community development agreement;

(ii) salaries and benefits of any person responsible for managing the 
implementation of one or more community development agreements where such responsibilities comprise over fifty percent $(50 \%)$ of that person's time;

(iii) social baseline studies (the gathering and compilation of baseline data that describes the state of the ecological, social and economic environment and characteristics of the populations living in the area);

(iv) social impact and opportunities assessment work (assessment of the potential ecological, social and economic impacts of the project upon communities and measures to offset potential negative impacts and maximize positive impacts);

(v) competencies assessment (measuring and recording the skills in a community);

(vi) participatory planning (the preparation of development program plans where community members participate in the planning effort);

(vii) community and mining operation mapping (maps depicting what the community perceives as its community space, where mining operations will take place and when, where access is open, restricted, or closed);

(viii) institutional analysis processes (processes for identifying and discussing what institutions are present in and around a community);

(ix) problem census taking (processes by which community members articulate the problems they consider need addressing in their community);

(x) implementation of [Local Authority] regional and community development 
program plans;

(xi) training programs for members of a qualified community;

(xii) consultation processes between the mining right holder and a qualified community or members of a qualified community and or local government which are related to the creation or implementation of a community development agreement;

(xiii) community development agreement monitoring;

(xiv) conflict management activities (the implementation of a grievance process, other than Court actions, as stipulated in a community development agreement);

(xv) such other expenditures as may be reasonably approved in writing by the [Director of the Mining Cadastre, Director of Mines, Minister, Ministry].

(b) to a total of not more than [ text ] percent ([ number ] \%) of the total of all expenditures claimed under (a), work that benefits more than a single qualified community that is not in furtherance of any individual community development agreement but such work is approved in writing by the [local planning authority] as qualifying as community development work (such as shared infrastructure);

(c) to a total of not more than [ text ] percent ([ number ] \%) of the total of all expenditures claimed under (a), administrative expenses;

(d) funds extended to a community in order for that community to build its capacity and enable it to effectively negotiate a community development agreement may be carried forward for expenditure reporting purposes to the first year 
of mineral sales and then claimed as a qualifying expenditure in equal amounts over the next five (5) years.

(5) The value of community development related work does not include:

(a) the payment by the holder of a mining right to any salaried worker it employs except as provided under sub-regulation 16(4)(a)(ii);

(b) the purchase of any good from a qualified community or community member that will be consumed by the project.

Ministry to respect community development agreements

Reporting requirements
18. - -

(1) The holder of a mining right shall [ semi-annually ] submit to the [Mining Cadastre Office, Department of Mines, Ministry] for every community development agreement to which it is a party -

(a) a report substantially as set out in Schedule 2 \{Community Development Agreement [ SemiAnnual ] Report \} no later than [ date ], describing objectives, activities, milestones and results for January through June in that calendar year,

(b) a report substantially as set out in Schedule 2 \{Community Development Agreement [ SemiAnnual ] Report \} no later than [ date ], describing objectives, activities, milestones and results for July through December during the prior calendar year, and

(c) a report and attachments substantially as set out in Schedule 3 \{Community Development Annual Expenditure Report\} not later than [ date ] detailing its community development expenditures and total expenditure for January through December during the prior calendar 
year, signed by the holder's resident manager: such report shall be sufficiently detailed, including a breakdown of expenditures as per sub-regulation 16(4), for the [Mining Cadastre Office, Department of Mines, Ministry] to verify that the amount and types of expenditure meet minimum expenditure requirements.

(2) The holder of a mining right shall submit the reports required in paragraphs (1)(a), (1)(b) and (1)(c) of this sub-regulation in [official language], but where a substantial proportion of the members of the qualified community which is party to the community development agreement being reported on are not fluent in [official language] the mining right holder shall submit such reports in both [official language] and in the local language or dialect used by that community.

Comment: Reports are necessary to enable the regulator to determine whether requirements are being met. An annual report should be the minimum reporting requirement, and more frequent reporting (semiannual, quarterly, monthly) may be useful in some circumstances. A semi-annual reporting requirement example is provided in the model regulation. 
Community development agreements and periodic reports available to the public
19.

(1) All community development agreements, community development agreement [semi-annual] reports and community development annual expenditure reports (including all required attachments) submitted by past and present holders of a mining right in furtherance of these regulations shall be open to free inspection by members of the public at the [Mining Cadastre Office, Department of Mines, Ministry] during normal Government office hours.

(2) On payment of the fee prescribed in Schedule 1 of these regulations, any member of the Public shall be entitled to obtain a copy from the [Mining Cadastre Office, Department of Mines, Ministry] of any community development agreement, community development agreement [ semi-annual] report, or community development annual expenditure report submitted by a past or present holder of a mining right.

(3) A community development agreement, community development agreement [semi-annual] reports and community development annual expenditure reports (including all required attachments) submitted by the holder of a mining right in furtherance of these regulations shall be open to free inspection by any member of the qualified community party to such agreement at the office of the mining right holder located closest to that community during normal office hours.

\section{Comment: This regulation insures transparency.}

\section{Transfer}

20. When a mining right is transferred to another party, the transferee shall be deemed to assume all rights and obligations of the transferor under any community development agreement relating to the mining right.

Comment: Mines often change ownership, and this provision provides a means to accommodate a change in mine ownership.

Penalties 21. A person who contravenes regulation 18(1) is guilty of an offence and is liable on summary conviction to a fine not exceeding $[X]$.

\section{Suspension of} mining rights
22. -

(1) The [Minister, Ministry, Director of Mines] may suspend without limit a mining right if the mining right holder fails to substantially comply with -

(a) sub-regulation 6(1) (requirement to have and implement community development agreements with all qualified communities); or 
(b) sub-regulation 6(2) (requirement to identify all qualified communities); or

(c) sub-regulation 16(1) (requirement to expend annual amount on community development).

(2) The [Minister, Ministry, Director of Mines] shall, before suspending any mining right give notice to the mining right holder and shall, in such a notice require the holder to remedy in not less than (90) ninety calendar days any breach of these regulations.

Comment: This regulation is important to achieve compliance. The threat of mining right suspension should insure that mining rights holders will substantially comply with the regulations.

Regulations to 23. The holder of a mining right that currently is in force but which apply to preexisting mining rights was granted prior to the adoption of these regulations is subject to these regulations and shall be in compliance with them no later than two calendar years from the publication date of these regulations.

Regulations to prevail if inconsistent with mining agreement
24. Should at any time any inconsistency occur between a provision in these regulations and terms or conditions in a mining agreement approved by the Government as an act of law, these regulations shall prevail unless such agreement came into force after these regulations and it specifically states that the mining agreement provisions shall prevail. 
Community Development Agreement Model Regulations and Example Guidelines

Prepared for the World Bank by James Otto

\section{Annex 2. Community Development Agreement Model Regulations}

1. Citation

2. Regulations supplement [Mining Act / Code Minier]

3. Object

4. Interpretation

5. General obligation to promote community development

6. Where community development agreement is required

7. Content of community development agreement

8. Capacity of community to negotiate

9. Approval of community development agreement

10. Community development agreements to compliment other agreements and development plans

11. One agreement may include more than one qualified community

12. Replacement of multiple agreements with single agreement

13. New community members

14. New communities

15. Only one agreement required where the community is the same

16. Minimum expenditure requirement

17. Ministry to respect community development agreements

18. Reporting requirements

19. Community development agreements and periodic reports available to the public

20. Transfer

21. Penalties

22. Suspension of mining rights

23. Regulations to apply to preexisting mining rights

24. Regulations to prevail if inconsistent with mining agreement

Schedule 1. Fees

Schedule 2. Community Development Agreement [ Semi-Annual ] Report Form

Schedule 3. Community Development Expenditure Annual Report Form

Citation, $\quad 1$ These regulations may be cited as the [Mining (Community commencment Development Agreement)] Regulations, 20[XX] and shall come into force on [date].

Regulations supplement [Mining Act ] Code Minier]
2. These regulations are supplemental to the [Mining Act/Code Minier] and the [General Mining Regulations] and are to be observed in conjunction therewith as far as practicable, but should at any time any inconsistency occur between a provision in these regulations and provisions in the [General Mining Regulations], the [General Mining Regulations] shall prevail. 
Object $3 . \quad$ The objects of these regulations are:

(a) to enhance the sustainable social, cultural and economic well-being of communities impacted by mining operations;

(b) to define when community development agreements are required and to provide a framework for such agreements;

(c) to ensure accountability and transparency in mining related community development.

Interpretation $4 . \quad$ In these regulations, except where otherwise expressly provided

“community development agreement" means a community development agreement approved pursuant to these regulations;

"general mining regulations" means [citation for the primary regulations made under the mining act/code minier];

“[Local Authority]” means [insert appropriate government entity];

"[Mining Act/Code Minier]" means [insert citation here for the mining act/code minier];

"mining right" means [name of the authorization that grants large scale mining rights under the mining law/code minier such as large scale mining licence, mining lease, mining concession, ...];

"[Minister, Ministry, Director of Mines]" means the [minister, ministry, Director of Mines] for the time being charged with the primary responsibility for mines and mining;

Alternative 1.

"qualified community" means a community that has the potential to be significantly negatively or positively impacted by mining operations;

Alternative 2.

"qualified community" means a community that has been specifically identified in an [environmental and social impact assessment] required under the [Environmental Protection Act] as having the potential to be significantly negatively or positively impacted by mining operations;

Alternative 3. 
"qualified community" means the single community of persons mutually agreed by the mining right holder and the [local authority]: Provided, if the mining right holder and [local authority] cannot agree on which community is the qualified community, the mining right holder may notify the [Minister, Ministry, Director of Mines] requesting clarification, and the [Minister, Ministry, Director of Mines] shall notify the mining right holder, specifying which community is the qualified community.

Alternative 4.

"qualified community" means a community of persons residing within [text (number)] kilometers of any boundary defining the mining right area.

"ratified community development agreement" means a community development agreement that has been approved by the respective community according to such process and in such manner as is customary for such community to make decisions on matters affecting the community as a whole.

"sub-community" means a group of persons classified as a subcommunity for the purposes of these regulations by the [Minister, Ministry, Director of Mines], in consultation with the [Local Authority], because their number is too small to comprise a qualified community, but who are for the purposes of these regulations deemed part of a qualified community.

General obligation to promote community development

Where community development agreement is required
5. The holder of a mining right shall assist in the development of communities affected by its operations to promote sustainable development, enhance the general welfare and the quality of life of the inhabitants, and shall recognize and respect the rights, customs, traditions and religion of local communities.

6. -

Alternative 1. The holder of a mining right is required to have and implement community development agreements with all qualified communities if its approved mining operation will or does exceed any of the following limits:

(a) in the case of extraction of minerals from primarily alluvial deposits, where annual throughput is more than $[x$ cubic metres $]$ per year; or 
(b) in the case of underground mining operations, where annual combined run-of-mine ore and waste production is more than $[x$ tonnes] per year (waste material not exiting mine mouth to be excluded); or

(c) in the case of open-cast mining operations extracting minerals from primarily non-alluvial deposits, where annual combined run-of-mine ore, rock, waste and overburden production is more than $[x]$ per year; or

(d) where the holder of a mining right employs or contracts or will employ or contract more than $[x]$ employees or workers at the mine site on a typical working day after the commencement of mineral production (including all shifts).

Alternative 2. The holder of a mining right is required to have and implement community development agreements with all qualified communities.

Alternative 3. If the holder of a mining right is required to complete and submit an environmental and social impact assessment under any law then in force and the assessment finds that communities may be significantly negatively or positively impacted by mining operations, the holder of the mining right is required to have and implement community development agreements with all qualified communities.

(2) The holder of a mining right shall-

(a) before commencing mine development (or where the mining right came into force before the publication date of these regulations and mine development has already commenced or has been completed, within one hundred and eighty (180) calendar days of such publication date), and

(b) at (5) five year intervals after the year in which mining commences (or where the mining right came into force before the publication date of these regulations and mining commenced before such publication date, at (5) year intervals from the date on 


$$
\text { which mining commenced), }
$$

identify all qualified communities and submit a draft list of such qualified communities to the [Minister, Ministry, Director of Mines], but if there are no qualified communities, this regulation does not apply.

(3) The [Minister, Ministry, Director of Mines], in consultation with the [Local Authority], shall within sixty (60) calendar days of receiving a submission under sub-regulation (2) approve or amend the draft qualified community list, and where it amends the list it shall notify the mining right holder explaining the reasons for such modification.

(4) Any community of persons may at any time notify the [Minister, Ministry, Director of Mines] that it believes it is a qualified community.

(5) The [Minister, Ministry, Director of Mines], in consultation with the [Local Authority], shall within sixty (60) calendar days of receiving a submission under sub-regulation (4) notify both the community of persons and the holder of the mining right whether the community of persons is a qualified community, and if it is not a qualified community, explain the reasons why not and whether it is to be considered a sub-community of a qualified community.

(6) The [Minister, Ministry, Director of Mines], in consultation with the [Local Authority], may reject the request submitted under subregulation (4) as a non-qualified community where that community of persons -

(a) does not meet the definition of a qualified community; or

(b) because of its small size is considered a subcommunity of a qualified community.

\section{Content of community development agreement}

\section{7. -}

(1) Subject to sub-regulation 7(3), the holder of a mining right who is required to have ratified community development agreements shall negotiate with each qualified community the terms of a community development agreement, and such agreements shall include at least the following provisions:

(a) the person, persons, board, committee, foundation, trust, forum, body or other entity which shall manage the agreement; 
(b) the person or body that represents the qualified community for the purposes of the agreement;

(c) the means by which a registry of persons comprising the community will be developed, maintained and updated;

(d) the means by which members of a qualified community will participate in the community's agreement related decision-making processes;

(e) the means by which the interests of women, youth, minority and marginalized groups and sub-communities of the qualified community will be represented in the community's agreement related decision-making processes and implementation;

(f) the goals and objectives of the community development agreement;

(g) a community development program plan which shall include at least the following::

(i) objectives,

(ii) milestones;

(iii)implementation timetable;

(iv) schedule of anticipated expenditures;

(v) metrics by which to measure progress;

(vi)periodic reporting including actual expenditures;

(vii) how the plan works in coordination with government plans, services, infrastructure and activities provided to or affecting the community;

(viii) how the provision of any service provided by the mining right holder to the community will be terminated or transferred to the community, government or other 
entity;

(ix)how and when the plan will be periodically updated;

(x) how the plan and amendments to the plan will be ratified by the community; and

(xi)such other content as may be mutually agreed by the community and the mining right holder;

(h) the roles and obligations of the holder of the mining right to the qualified community, which may or may not be part the development program plan required under sub-regulation 7(1)(g), including but not limited to:

(i) undertakings with respect to the social and economic contributions that the project will make to the sustainability of the community;

(ii) assistance in creating self-sustaining, income-generating activities, such as but not limited to, production of goods and services needed by the mine and the community;

(iii) consultation with the community in the planning of mine closure and postclosure measures that seek to prepare the community for the eventual closure of the mining operations;

(i) the roles and obligations of the qualified community to the holder of the mining right;

(j) the roles and obligations of the [Local Authority], if it is a party to the community development agreement or otherwise so chooses to be obligated;

(k) the means by which the community development agreement shall be reviewed by the holder of the mining right and qualified community every five 
(5) calendar years, and the commitment to be bound by the current agreement in the event that any modifications to the agreement sought by one party cannot be mutually agreed with the other party;

(1) the consultative and monitoring frameworks between the holder of the mining right and the qualified community, and the means by which the community may participate in the planning, implementation, management, measurement (including indicators) and monitoring of activities carried out under the agreement;

(m) the language(s) to be used in the preparation of reports, plans, and other written matters required under the agreement;

(n) the means by which any funds made available under the agreement are to be disbursed, for what purposes they may be disbursed, what accounts must be kept and by whom, and reporting and auditing requirements;

(o) the mechanisms whereby the qualified community, and sub-communities and members of the qualified community may lodge a grievance with the mining right holder;

(p) the mechanisms whereby the mining right holder may lodge a grievance with the qualified community;

(q) a statement to the effect that both the holder of the mining right and qualified community agree that any dispute regarding the agreement shall in the first instance be resolved by consultation between the holder and the qualified community representative(s);

(r) the dispute resolution mechanism to be used when consultation between the holder and the qualified community representative(s) fails;

(s) the process by which the agreement may be modified; 
(t) severability of articles;

(u) the applicable law, which shall be the law of [name of country];

(v) reasons and procedure for declaring force majeure;

(w) duration of the agreement;

(x) suspension / termination of the agreement;

(y) assignment of the agreement or any right or obligation there under;

(z) transfer of all community development agreement rights and obligations to any party to whom the mining right holder transfers its mining right;

(aa) how notifications to respective parties shall be done;

(bb) location where the agreement may be accessed by members of the community;

(cc) the agreement signatories, which may for the qualified community be the representatives of the community, representatives of subcommunities comprising the community, community members or any combination thereof, non-governmental organizations, and others as the need requires.

(2) Subject to sub-regulation 7(3), a community development agreement shall take into account the unique circumstances of the holder of the mining right and qualified community, and the issues to be addressed in the agreement and development program plan may include all or some or none of the following: -

(a) role of local government;

(b) educational scholarship, apprenticeship, technical training and employment opportunities for the people of the community; 
(c) employment quota or percentage allocation for sub-communities;

(d) financial or other forms of contributory support for infrastructural development and maintenance such as education, health or other community services, roads, water and power;

(e) assistance with the creation, development and support to small-scale and micro enterprises;

(f) special programs which benefit women;

(g) special program which benefit youth;

(h) special programs which benefit sub-communities within the qualified community;

(i) agricultural product marketing;

(j) protection of natural resources;

(k) support for cultural heritage and sports;

(1) treatment of cultural and sacred sites;

(m) treatment of ecological systems, including restoration and enhancement, for traditional activities such as hunting and gathering;

(n) language training to further employment prospects;

(o) how cultural values will be respected;

(p) cross-cultural training requirements;

(q) malaria, AIDs and drug dependency prevention and intervention;

(r) land access;

(s) the assumption of specified obligations of the mining right holder by the qualified community, sub-communities and/or government on an 
evolving basis and/or upon termination of the agreement;

(t) methods and procedures of environment and socio-economic management, and local governance enhancement;

(u) requirements with regard to third parties such as the mining right holder's contractors and suppliers;

(v) the involvement of non-governmental organizations; and

(w) other matters as may be agreed.

(3) Goals, objectives, obligations and activities specified in a community development agreement should aim to achieve sustained community development which -

(a) lasts from generation to generation;

(b) is based on the actual needs of the community;

(c) is maintainable within available income;

(d) is well planned, monitored and evaluated;

(e) has long term benefits;

(f) prepares the community for closure of the mine;

(g) compliments but does not replace governmentled development and services;

(h) is in accord and compliments local and regional government development plans;

(i) recognizes and incorporates traditional knowledge.

(4) The [Local Authority] may be but is not required to be a party to a community development agreement.

(5) A community development agreement may not address any of the following matters - 
(a) the imposition of any additional rent, fee, or tax for the benefit of the qualified community that is not set out by law;

(b) the provision of any passenger car, small truck, or four-by-four vehicle to any individual or single family unit of the qualified community or to the qualified community, other than a specialized purpose vehicle such as an ambulance, fire engine, water truck, or bus;

(c) the provision of any monetary amount, service, good, or facility for the sole benefit of an individual or single family unit; or

(d) any matter that is illegal under any law then in force.

(6) A community development agreement shall be in [official language] but where a substantial proportion of the community members are not fluent in [official language], the mining right holder party to such agreement shall make available to representatives of the qualified community translated unofficial copies in the local language or dialect.

Capacity of community to negotiate
8. Where a qualified community lacks the capacity to effectively negotiate a community development agreement, the mining right holder shall assist to build that capacity including the provision of such funds to the community for capacity-building and preparation as are reasonable in the circumstances.

9.

(1) A community development agreement or revised community development agreement agreed and signed by the authorized representatives of a holder of a mining right and a qualified community shall be submitted for approval to the [Minister, Ministry, Director of Mines] who shall, if the agreement meets the requirements set out in regulation 7, approve such agreement within forty-five (45) calendar days of it being submitted.

(2) The holder of a mining right submitting a community development agreement for approval shall pay the non-refundable processing fee specified in Schedule 1.

(3) A community development agreement shall come into force upon its approval by the [Minister, Ministry, Director of Mines]. 
(4) If a community development agreement or revised community development agreement is not approved, the [Minister, Ministry, Director of Mines] shall notify both the holder of mining right and the qualified community representative, and such notices shall contain the specific reasons for denial and the means or directions by which such reasons may be corrected.

(5) The [Minister, Ministry, Director of Mines] shall cause, within thirty (30) calendar days from the date on which a notification is made under paragraph (4) of this sub-regulation, a copy of the notification to be put on open file at the [Mining Cadastre Office, Department of Mines, Ministry] for access by the public.

(6) The holder of the mining right and the qualified community representatives may submit any number of revised community development agreements and such submissions do not require the payment of any additional processing fee.

(7) If the holder of the mining right and a qualified community are unable to agree on the terms of a community development agreement, they may by mutual consent seek to resolve their differences through mediation.

(8) If the holder of the mining right and a qualified community fail after reasonable good faith attempts to conclude a community development agreement by the time the mining right holder is ready to commence development work on the mining rights area, the holder or the qualified community may refer the matter, jointly or individually, by notification to the [Minister, Ministry, Director of Mines] for resolution, and the decision of the [Minister, Ministry, Director of Mines], in consultation with the [Local Authority], thereon shall be final.

(9) A notification under sub-regulation (8) from either or both parties shall include the draft community development agreement proposed by the party, description of the efforts to negotiate an agreement or revised agreement, issues that have been agreed, issues which have not been agreed, and proposals to resolve issues, and the [Minister, Ministry, Director of Mines] shall determine the matter within sixty (60) calendar days of such notification.

(10) The [Minister, Ministry, Director of Mines] shall within thirty (30) calendar days from the date on which a community development agreement is approved cause a copy of the agreement or revised agreement to be put on open file at the [Mining Cadastre Office, Department of Mines, Ministry]. 
Community development agreements to compliment other agreements and development plans
10. The holder of a mining right that is required to enter into a community development agreement with a qualified community shall take into consideration --

(a) any community development agreements it has with other qualified communities so that such agreements compliment one another to achieve synergistic development across the communities;

(b) any existing community development agreements entered into by that qualified community with other holders of mining rights so that its community development agreement compliments such existing agreements, and such mining right holder may, but is not required to, become a party to any such existing agreements;

(c) any government local or regional development plans or schemes so that the agreement is in harmony with and compliments such plans or schemes; and

(d) any government services provided or which will be provided to a qualified community so as not to displace that service.
One agreement may include more than one qualified community

Replacement of multiple agreements with single agreement
11. Where the holder of a mining right is required to enter into ratified community development agreements with more than one qualified community, the holder may enter into one or several community development agreements that include multiple qualified communities, but the holder must have a separate community development agreement with a qualified community that does not want to be part of a multiple party agreement.

12. Where the holder of a mining right has entered into more than one ratified community development agreement and the parties to two or more of these agreements now want to replace their agreements with a single community development agreement, such new agreement shall be submitted for approval under regulation 9. 
New community 13. Any person or group of persons not appearing in the registry of members persons constituting a qualified community may with the approval of the body responsible for the management of a CDA be added to such registry at any time and shall then be considered a member of that qualified community.

New communities 14. Any community of persons that is not approved and listed by the [Minister, Ministry, Director of Mines] as a qualified community

(a) on the date that a mining right holder commenced mining operations (if after the publication date of these regulations), or

(b) one hundred and eighty calendar days (180) after the publication date of these regulations (if mining operations commenced before such publication date)

is not a qualified community and a community development agreement with such a community shall be at the option of the mining right holder.

Only one agreement required where the community is the same

\section{Minimum expenditure requirement}

15. Where a person is the holder of more than one mining right and these regulations would otherwise require the holder to enter into a ratified community development agreement with the same community under each mining right, only a single community development agreement and [ semi-annual ] community development report are required with regard to that community.

16. -

(1) The holder of a mining right who has entered into one or more ratified community development agreements shall expend

(i) in the first calendar year following the commencement of mineral sales, no less than [ text ] percent ([ number ] \%) of the gross revenue amount earned pursuant to that right from mineral sales in the previous calendar year;

(ii) in the second calendar year following the commencement of mineral sales, no less than [ text ] percent ([ number] \%) of the gross revenue amount earned pursuant to that right from mineral sales in the previous two calendar years divided by two (2);

(iii)in the third calendar year following the commencement of mineral sales and in each subsequent calendar year no less than [ text ] percent ([ number ] \%) of the gross revenue 
amount earned pursuant to that right from mineral sales in the previous three calendar years divided by three (3)

to implement the agreement(s) or otherwise promote community development.

(2) If during any calendar year, the holder of a mining right expends an amount on community development in excess of the annual minimum expenditure amount required, such excess amount may be applied to satisfy up to [ text ] percent ([ number ] \%) of its expenditure requirement in the next calendar year.

(3) If during any calendar year during the term of the mining right the holder thereof does not expend an amount at least equal to the minimum annual expenditure amount required under sub-regulation 16(1), including any excess amount carried forward from the previous calendar year pursuant to sub-regulation 16(2), the mining right shall be subject to suspension.

(4) The value of community development related work, if the expenditures are reasonable, documented in sufficient detail to establish their authenticity to the satisfaction of the [Director of the Mining Cadastre, Director of Mines, Minister, Ministry], and directly related to the objectives of one or more ratified community development agreements includes:

(a) at full cost, whether incurred directly by the mining right holder or indirectly through payments to a contractor, community trust, community foundation or other legal entity,

work or funds irrevocably committed to fulfill any obligation of the mining right holder specified in a ratified community development agreement;

(ii) salaries and benefits of any person responsible for managing the implementation of one or more community development agreements where such responsibilities comprise over fifty percent $(50 \%)$ of that person's time;

(iii) social baseline studies (the gathering and compilation of baseline data that describes the state of the ecological, 
social and economic environment and characteristics of the populations living in the area);

(iv) social impact and opportunities assessment work (assessment of the potential ecological, social and economic impacts of the project upon communities and measures to offset potential negative impacts and maximize positive impacts);

(v) competencies assessment (measuring and recording the skills in a community);

(vi) participatory planning (the preparation of development program plans where community members participate in the planning effort);

(vii) community and mining operation mapping (maps depicting what the community perceives as its community space, where mining operations will take place and when, where access is open, restricted, or closed);

(viii) institutional analysis processes (processes for identifying and discussing what institutions are present in and around a community);

(ix) problem census taking (processes by which community members articulate the problems they consider need addressing in their community);

(x) implementation of [Local Authority] regional and community development plans;

(xi) training programs for members of a qualified community;

(xii) consultation processes between the mining right holder and a qualified community or members of a qualified 
community and or local government which are related to the creation or implementation of a community development agreement;

(xiii) community development agreement monitoring;

(xiv) conflict management activities (the implementation of a grievance process, other than Court actions, as stipulated in a community development agreement);

(xv) such other expenditures as may be reasonably approved in writing by the [Director of the Mining Cadastre, Director of Mines, Minister, Ministry].

(b) to a total of not more than [ text ] percent ([ number \% ]) of the total of all expenditures claimed under (a), work that benefits more than a single qualified community that is not in furtherance of any individual community development agreement but such work is approved in writing by the [local planning authority] as qualifying as community development work (such as shared infrastructure);

(c) to a total of not more than [ text ] percent ([ number \% ]) of the total of all expenditures claimed under (a), administrative expenses;

(d) funds extended to a community in order for that community to build its capacity and enable it to effectively negotiate a community development agreement may be carried forward for expenditure reporting purposes to the first year of mineral sales and then claimed as a qualifying expenditure in equal amounts over the next five (5) years.

(5) The value of community development related work does not include:

(a) the payment by the holder of a mining right to 
any salaried worker it employs except as provided under sub-regulation 16(4)(a)(ii);

(b) the purchase of any good by the holder of a mining right from a qualified community or community member that will be consumed or sold by the holder.

Ministry to respect community development agreements

Reporting requirements
17. The Ministry shall use its best efforts to respect and facilitate approved community development agreements.

18. -

(1) The holder of a mining right shall [ semi-annually ] submit to the [Mining Cadastre Office, Department of Mines, Ministry] for every community development agreement to which it is a party -

(a) a report substantially as set out in Schedule 2 \{Community Development Agreement [SemiAnnual] Report $\}$ no later than [date], describing objectives, activities, milestones and results for January through June in that calendar year,

(b) a report substantially as set out in Schedule 2 \{Community Development Agreement [SemiAnnual] Report\} no later than [date], describing objectives, activities, milestones and results for July through December during the prior calendar year, and

(c) a report and attachments substantially as set out in Schedule 3 \{Community Development Annual Expenditure Report\} not later than [date] detailing its community development expenditures and total expenditure for January through December during the prior calendar year, signed by the holder's resident manager: such report shall be sufficiently detailed, including a breakdown of expenditures as per sub-regulation 16(4), for the [Mining Cadastre Office, Department of Mines, Ministry] to verify that the amount and types of expenditure meet minimum expenditure requirements. 
(2) The holder of a mining right shall submit the reports required in paragraphs (1)(a), (1)(b) and (1)(c) of this sub-regulation in [official language], but where a substantial proportion of the members of the Qualified Community which is party to the Community Development Agreement being reported on are not fluent in [official language] the mining right holder shall submit such reports in both [official language] and in the local language or dialect used by that community.

\section{Community development agreements and periodic reports available to the public}

Transfer

Penalties

Suspension of mining rights
19. -

(1) All community development agreements, community development agreement [ semi-annual ] reports and community development annual expenditure reports (including all required attachments) submitted by past and present holders of a mining right in furtherance of these regulations shall be open to free inspection by members of the public at the [Mining Cadastre Office, Department of Mines, Ministry] during normal Government office hours.

(2) On payment of the fee prescribed in Schedule 1 of these regulations, any member of the Public shall be entitled to obtain a copy from the [Mining Cadastre Office, Department of Mines, Ministry] of any community development agreement, community development agreement [ semi-annual ] report, or community development annual expenditure report submitted by a past or present holder of a mining right.

(3) A community development agreement, community development agreement annual reports and community development annual expenditure reports (including all required attachments) submitted by the holder of a mining right in furtherance of these regulations shall be open to free inspection by any member of the qualified community party to such agreement at the office of the mining right holder located closest to that community during normal office hours.

20. When a mining right is transferred to another party, the transferee shall be deemed to assume all rights and obligations of the transferor under any community development agreement relating to the mining right.

21. A person who contravenes regulation 18(1) is guilty of an offence and is liable on summary conviction to a fine not exceeding $[X]$.

22. -

(1) The [Minister, Ministry, Director of Mines] may suspend without limit a mining right if the mining right holder fails to substantially comply with -

(a) sub-regulation 6(1) (requirement to have and 
implement community development agreements with all qualified communities); or

(b) sub-regulation 6(2) (requirement to identify all qualified communities); or

(c) sub-regulation 16(1) (requirement to expend annual amount on community development).

Regulations to apply to preexisting mining rights

Regulations to prevail if inconsistent with mining agreement
(2) The [Minister, Ministry, Director of Mines] shall, before suspending any mining right give notice to the mining right holder and shall, in such a notice require the holder to remedy in not less than (90) ninety calendar days any breach of these regulations.

23. The holder of a mining right that currently is in force but which was granted prior to the adoption of these regulations is subject to these regulations and shall be in compliance with them no later than two calendar years from the publication date of these regulations.

24. Should at any time any inconsistency occur between a provision in these regulations and terms or conditions in a mining agreement approved by the Government as an act of law, these regulations shall prevail unless such agreement came into force after these regulations and it specifically states that the mining agreement provisions shall prevail.

\section{SCHEDUle 1. FEeS}

Community development agreement processing fee

Copy of community development agreement

Copy of community development agreement [ semi-annual ] report

Copy of community development expenditure annual report
[?]

[?] per page

[?] per page

[?] per page 


\section{SChEdule 2. Community DeVElopMent AgREEMENT [SEMI-ANNUAL] REPORT Form}

1. Name of mining right holder:

2. Mining right registration number:

3. Year: Period being reported:

4. Name or description of qualified community:

5. Year in which the community development agreement with the qualified community was originally approved:

6. Year in which the community development agreement was last amended and such amendment was approved:

7. Attach an explanation addressing the following points:

○ description the goals of the community development agreement;

- description of the community development objectives and how they are to be met;

- community development agreement activities, milestones and results for the period being reported;

- development program plan activities, milestones, expenditures and results for the period being reported;

- description of community related challenges encountered, how these challenges are or may effect the project, and how the challenges are or will be addressed;

- description of environmental and social impacts of community development agreement activities;

- other information as may be requested in writing by the [Director of the Mining Cadastre, Director of Mines, Minister];

o other information which the mining right holder wants to report; and

any such descriptions and information shall be sufficiently detailed so that the [Director of the Mining Cadastre, Director of Mines, Minister, Ministry] can determine whether the community development agreement is succeeding.

\section{Attestation of truth and accuracy}

This report has been prepared under my supervision. The report is truthful and substantially accurate in all its details.

Signature:

Name:

Email:

Fax:
Date:

Position:

Telephone:

Address: 


\section{SChEDUle 3. COMMUNity DEVELOPMENT EXPENDITURE ANNUAL REPORT ForM}

1. Name of mining right holder:

2. Mining right registration number:

3. Calendar year for which expenditures are being reported:

4. Year in which mineral sales were first earned under the mining right:

5. Calculate Gross Mineral Sales Revenues

If mineral sales first commenced in the preceding calendar year;

Sales: January 1 through December 31 of year preceding calendar year):

Gross Mineral Sales Revenue:

If mineral sales first commenced two years before this calendar year:

Sales:January 1 through December 31 of $1^{\text {st }}$ year preceding this year:

+ Sales:January 1 through December 31 of $2^{\text {nd }}$ year preceding this year)

total:

divide total by 2

Gross Mineral Sales Revenue:

If mineral sales first commenced three years or more before this calendar year:

Sales: January 1 through December 31 of $1^{\text {st }}$ year preceding this year:

+ Sales: January 1 through December 31 of $2^{\text {nd }}$ year preceding this year:

+ Sales: January 1 through December 31 of $3^{\text {rd }}$ year preceding this year:

total::

divide total by 3

Gross Mineral Sales Revenue:

6. Calculate required community development expenditure for last calendar year

Respective Gross Mineral Sales Revenue from $\{5\}$

Required Community Development Expenditure:

$\underline{\mathrm{x}}[X \%]$

7. Calculate permissible carry-over from calendar year preceding last calendar year

Required community development expenditure (from $\{6\}$ ):

a. Maximum allowed carry-over:

$\underline{\mathrm{x}}[X \%]$

b. Excess amount carried over from year preceding last calendar year:

Permissible Carry-Over (enter smaller of $\{a\}$ or $\{b\}$ )

Note: excess community development expenditure may be carried over for one year only; i.e. there is no cumulative carry over. 
Community Development Agreement Model Regulations and Example Guidelines

Prepared for the World Bank by James Otto

8. Calculate required new community development expenditure for last calendar year

Required Community Development Expenditure (from $\{6\}$ )

less Permissible Carry-Over (from $\{7\}$ )

Required New Community Development Expenditure for Last Calendar Year:

9. Calculate actual community development expenditure for last calendar year

Notes:

Report here only expenditures that are supported by documentation. Such documentation need not be submitted with this report but must be made available upon request.

Expenditures reported here include those incurred directly by the mining right holder or indirectly through payments by the mining right holder to a contractor, community trust, community foundation or other legal entity for the listed item.

\begin{tabular}{|c|c|}
\hline Type of Expenditure & $\begin{array}{l}\text { Expenditure } \\
\text { amount }\end{array}$ \\
\hline $\begin{array}{l}\text { a. work or funds irrevocably committed to fulfill any obligation of the } \\
\text { mining right holder specified in a community development agreement } \\
\text { (attachment(s) required: for every community development agreement } \\
\text { attach a detailed list of expenditures made with regard to that } \\
\text { agreement, sum the expenditures for each agreement, and enter the total } \\
\text { of those sums here) }\end{array}$ & \\
\hline $\begin{array}{l}\text { b. salaries and benefits of any person responsible for managing the } \\
\text { implementation of one or more community development agreements where } \\
\text { such responsibilities comprise over fifty percent }(50 \%) \text { of that person's time }\end{array}$ & \\
\hline $\begin{array}{l}\text { c. social baseline studies (the gathering and compilation of baseline data } \\
\text { that describes the state of the ecological, social and economic environment } \\
\text { and characteristics of the populations living in the area) }\end{array}$ & \\
\hline $\begin{array}{l}\text { d. social impact and opportunities assessment work (assessment of the } \\
\text { potential ecological, social and economic impacts of the project upon } \\
\text { communities and measures to offset potential negative impacts and maximize } \\
\text { positive impacts) }\end{array}$ & \\
\hline $\begin{array}{l}\text { e. competencies assessment (measuring and recording the skills in a } \\
\text { community) }\end{array}$ & \\
\hline $\begin{array}{l}\text { f. participatory planning (the preparation of development program plans } \\
\text { where community members participate in the planning effort) }\end{array}$ & \\
\hline $\begin{array}{l}\text { g. community and mining operation mapping (maps depicting what the } \\
\text { community perceives as its community space, where mining operations will } \\
\text { take place and when, where access is open, restricted, or closed) }\end{array}$ & \\
\hline $\begin{array}{l}\text { h. institutional analysis processes (processes for identifying and discussing } \\
\text { what institutions are present in and around a community) }\end{array}$ & \\
\hline $\begin{array}{l}\text { i. problem census taking (processes by which community members } \\
\text { articulate the problems they consider need addressing in their community) }\end{array}$ & \\
\hline j. implementation of [Local Authority] regional and community & \\
\hline
\end{tabular}




\begin{tabular}{|c|c|}
\hline $\begin{array}{l}\text { development plans } \\
\text { k. training programs for members of a qualified communities (if not }\end{array}$ & \\
\hline $\begin{array}{l}\text { k. training programs for members of a qualified communities (if not } \\
\text { included in }\{a\} \text { ) }\end{array}$ & \\
\hline $\begin{array}{l}\text { 1. consultation processes between the mining right holder and a qualified } \\
\text { community or members of a qualified community and or local government } \\
\text { which are related to the creation or implementation of a community } \\
\text { development agreement }\end{array}$ & \\
\hline m. community development agreement monitoring; & \\
\hline $\begin{array}{l}\text { n. conflict management activities (the implementation of a grievance } \\
\text { process, other than court actions, as stipulated in a community development } \\
\text { agreement) }\end{array}$ & \\
\hline $\begin{array}{l}\text { o. such other expenditures as may be reasonably approved in writing by the } \\
\text { [Director of the Mining Cadastre, Director of Mines, Minister, Ministry]. } \\
\text { (attachment(s) required: attach approval letter(s), only expenditures } \\
\text { with approval letters qualify) }\end{array}$ & \\
\hline p. Subtotal (sum of $\{a\}$ through $\{o\})$ & \\
\hline $\begin{array}{l}\text { q. to a total of not more than }[\text { text }] \text { percent }([\text { number }] \%) \text { of subtotal }\{\mathrm{p}\} \text {, } \\
\text { expenditure other than }\{\mathrm{a}\} \text { through }\{\mathrm{o}\} \text { that benefits more than a single } \\
\text { qualified community that is not in furtherance of any individual community } \\
\text { development agreement but such work is approved in writing by the [Local } \\
\text { Planning Authority] as qualifying as community development work } \\
\text { (example: approved shared or regional infrastructure) } \\
\text { (attachment(s) required: attach approval letter(s), only expenditures } \\
\text { with approval letters qualify) }\end{array}$ & \\
\hline $\begin{array}{l}\text { r. to a total of not more than }[\text { text }] \text { percent }([\text { number }] \%) \text { of subtotal }\{\mathrm{p}\} \text {, } \\
\text { administrative expenses. }\end{array}$ & \\
\hline $\begin{array}{l}\text { s. community capacity building expenditure deduction as per regulation } \\
16(4)(d)\end{array}$ & \\
\hline $\begin{array}{l}\text { t. Total Annual Community Development Expenditure } \\
\{\mathbf{p}\}+\{\mathbf{q}\}+\{\mathbf{r}\}+\{\mathbf{s}\}\end{array}$ & \\
\hline
\end{tabular}

10. Calculate shortfall or excess new community development expenditure for the last calendar year

Required New Community Development Expenditure for last

Calendar Year (from $\{8\}$ ):

less annual community development expenditure last year (from $\{9 \mathrm{t}\}$ )

If negative, enter shortfall here:

If positive, enter excess to carry forward to report next year: 
Community Development Agreement Model Regulations and Example Guidelines

Prepared for the World Bank by James Otto

\section{Attestation of truth and accuracy}

This report has been prepared under my supervision. The report is truthful and substantially accurate in all its details, and documentation is available to verify all expenditures.

Signature:

Date:

Name:

Position:

Email:

Telephone:

Fax:

Address: 


\section{AnNex 3. Example of Community Development Agreement Guidelines}

The guidelines provided in this Annex are one example of how the model community development regulations set out in Annex 1 can be modified from regulations into guidelines. Some governments prefer guidelines to have a completely voluntary basis (as in the example presented in this Annex). Other governments may legislate that a mining right holder must have agreements that conform to strict administrative guidelines, in which case the example below would require modification. Guidelines are drafted in many different formats to reflect governments' preferences. The example format below reflects a "formal" style, but could be modified to a narrative textual description or bulleted style.

Guideline:

1. Citation, publication

2. Object

3. Interpretation

4. Mining right holder may assist in development of communities

5. Capacity to negotiate

6. Recommended content of community development agreement

7. Community development agreements should compliment other agreements and development plans

8. Recommended minimum expenditure

9. Transparency through reporting

10. Community development agreements and annual reports available to the public

11. Transfer

12. Preexisting mining rights

Schedule 1. Community Development Agreement [ Semi-Annual ] Report Form

Schedule 2. Community Development Expenditure Annual Report Form 
Citation, publication

Object

Interpretation
1. These guidelines may be cited as the [Mining (Community Development Agreement)] Guidelines, 20[XX] and their publication date is [date].

2. The objects of these guidelines are:

(a) to enhance the sustainable social, cultural and economic well-being of communities impacted by mining operations;

(b) to define when community development agreements may be useful and to provide a suggested framework for such agreements;

(c) to promote accountability and transparency in mining related community development.

3. In these guidelines, except where otherwise expressly provided

"community development agreement" means a community development agreement negotiated between the holder of a mining right and a partner community;

"[Local Authority]" means [insert appropriate government entity];

"[Mining Act/Code Minier]" means [insert citation here for the mining act/code minier];

"mining right" means [name of the authorization that grants large scale mining rights under the mining law/code minier such as large scale mining licence, mining lease, mining concession, ...];

"partner community" means a community, in proximity to an area covered by a mining right, that has the potential to be significantly negatively or positively impacted by mining operations;

"ratified community development agreement" means a community development agreement that has been approved by the respective community according to such process and in such manner as is customary for such community to make decisions on matters affecting the community as a whole.

"sub-community" means a group of persons classified as a subcommunity for the purposes of these guidelines because their number 
is too small to comprise a partner community, but are part of a partner community.

\section{Mining right holder may assist in development of communities}

\section{Capacity to negotiate}

\section{Recommended content of community development agreement}

4. It is recommended that a mining right holder assist in the development of communities affected by its operations to promote sustainable development, enhance the general welfare and the quality of life of the inhabitants, and recognize and respect the rights, customs, traditions and religion of local communities.

5. Where a qualified community lacks the capacity to effectively negotiate a community development agreement, it is recommended that the mining right holder assist to build that capacity including the provision of such funds to the community for capacity-building and preparation as are reasonable in the circumstances.

$6 . \quad-$

(1) It is recommended that a mining right holder negotiate with each partner community a ratified community development agreement, and each such agreement might include at least the following provisions:

(a) the person, persons, board, committee, foundation, trust, forum, body or other entity which shall manage the agreement;

(b) the person or body that represents the partner community for the purposes of the agreement;

(c) the means by which a registry of persons comprising the community will be developed, maintained and updated;

(d) the means by which members of a partner community will participate in the community's agreement related decision-making processes;

(e) the means by which the interests of women, youth and sub-communities of the partner community will be represented in the community's agreement related decision-making processes and implementation;

(f) the goals and objectives of the community development agreement;

(g) a community development program plan which might include at least the following:: 
(i) objectives,

(ii) milestones;

(iii)implementation timetable;

(iv) schedule of anticipated expenditures;

(v) metrics by which to measure progress;

(vi)periodic reporting including actual expenditures;

(vii) how the plan works in coordination with government plans, services, infrastructure and activities provided to or affecting the community;

(viii) how the provision of any service provided by the mining right holder to the community will be terminated or transferred to the community, government or other entity;

(ix)how and when the plan will be periodically updated;

(x) how the plan and amendments to the plan will be ratified by the community; and

(xi) such other content as may be mutually agreed by the community and the mining right holder;

(h) the roles and obligations of the holder of the mining right to the partner community, which may or may not be part the development program plan recommended under sub-paragraph $6(1)(\mathrm{g})$, including but not necessarily limited to:

(i) undertakings with respect to the social and economic contributions that the project will make to the sustainability of the community;

(ii) assistance in creating self-sustaining, income-generating activities, such as but not limited to, production of goods and services needed by the mine and the community; 
(iii)consultation with the community in the planning of mine closure and post-closure measures that seek to prepare the community for the eventual closure of the mining operations;

(i) the roles and obligations of the partner community to the holder of the mining right;

(j) the roles and obligations of the [Local Authority], if it is a party to the community development agreement or otherwise so chooses to be obligated;

(k) the means by which the community development agreement shall be reviewed by the holder of the mining right and partner community every five (5) calendar years, and the commitment to be bound by the current agreement in the event that any modifications to the agreement sought by one party cannot be mutually agreed with the other party;

(1) the consultative and monitoring frameworks between the holder of the mining right and the partner community, and the means by which the community may participate in the planning, implementation, management, measurement (including indicators) and monitoring of activities carried out under the agreement;

(m) the language(s) to be used in the preparation of reports, plans, and other written matters required under the agreement;

(n) the means by which any funds made available under the agreement are to be disbursed, for what purposes they may be disbursed, what accounts must be kept and by whom, and reporting and auditing requirements;

(o) the mechanisms whereby the partner community, and sub-communities and members of the partner community may lodge a grievance with the mining right holder;

(p) the mechanisms whereby the mining right holder may lodge a grievance with the partner community;

(q) the process by which the agreement may be modified; 
(r) a statement to the effect that both the holder of the mining right and partner community agree that any dispute regarding the agreement shall in the first instance be resolved by consultation between the holder and the partner community representative(s);

(s) the dispute resolution mechanism to be used when consultation between the holder and the partner community representative(s) fails;

(t) severability of articles;

(u) the applicable law, which shall be the law of [name of country];

(v) reasons and procedure for declaring force majeure;

(w) duration of the agreement;

(x) suspension / termination of the agreement;

(y) assignment of the agreement or any right or obligation there under;

(z) transfer of all community development agreement rights and obligations to any party to whom the mining right holder transfers its mining right;

(aa) how notifications to respective parties shall be done;

(bb) location where the agreement may be accessed by members of the community;

(cc) the agreement signatories, which may for the partner community be the representatives of the community, representatives of sub-communities comprising the community, community members or any combination thereof, non-governmental organizations, and others as the need requires.

(2) In addition to the subject matter listed in (1) above, it is recommended that a community development agreement take into account the unique circumstances of the mining right holder and partner community, and the issues to be addressed in the agreement and development program plan might address all or some or none of the 


\section{following issues: -}

(a) role of local and other levels of government;

(b) educational scholarship, apprenticeship, technical training and employment opportunities for the people of the community;

(c) employment quota or percentage allocation for subcommunities;

(d) financial or other forms of contributory support for infrastructural development and maintenance such as education, health or other community services, roads, water and power (in consultation with relevant government authorities);

(e) assistance with the creation, development and support to small-scale and micro enterprises;

(f) special programs which benefit women;

(g) special programs which benefit youth;

(h) special programs which benefit sub-communities within the partner community;

(i) agricultural product marketing;

(j) protection of natural resources;

(k) support for cultural heritage and sports;

(1) treatment of cultural and sacred sites;

(m) treatment of ecological systems, including restoration and enhancement, for traditional activities such as hunting and gathering;

(n) language training to further employment prospects;

(o) how cultural values will be respected;

(p) cross-cultural training requirements;

(q) malaria, AIDs and drug dependency prevention and 
intervention;

(r) land access;

(s) the assumption of specified obligations of the mining right holder by the partner community, sub-communities and/or government authorities on an evolving basis and/or upon termination of the agreement;

(t) methods and procedures of environment and socioeconomic management, and local governance enhancement;

(u) coordination with local and national government development plans affecting the community;

(v) requirements with regard to third parties such as the mining right holder's contractors and suppliers;

(w) the involvement of non-governmental organizations; and

(x) other matters as may be agreed.

(3) It is recommended that goals, objectives, obligations and activities specified in a community development agreement aim to achieve sustained community development which -

(a) lasts from generation to generation;

(b) is based on the actual needs of the community;

(c) is maintainable within available income;

(d) is well planned, monitored and evaluated;

(e) has long term benefits;

(f) prepares the community for closure of the mine;

(g) compliments but does not replace government-led development and services;

(h) is in accord and compliments local and regional government development plans;

(i) recognizes and incorporates traditional knowledge. 
(4) It is recommended that a mining right holder and partner community consider what role the [Local Authority] may have in regard to a community development agreement, whether that role should be described in such agreement, and whether it would be appropriate for the [Local Authority] to be a party to such agreement.

(5) It is suggested that a community development agreement not address any of the following matters -

(a) the provision of any passenger car, small truck, or fourby-four vehicle to any individual or single family unit of the partner community or to the partner community, other than a specialized purpose vehicle such as an ambulance, fire engine, water truck, or bus; or

(b) the provision of any monetary amount, service, good, or facility for the sole benefit of an individual or single family unit.

(6) It is recommended that a community development agreement be in [official language] but where a substantial proportion of the community members are not fluent in [official language], the mining right holder party to such agreement should consider making available to representatives of the partner community translated copies in the local language or dialect.

Community development agreements should compliment other agreements and development plans
7. It is recommended that a mining right holder that enters into a community development agreement with a partner community take into consideration --

(a) any community development agreements it has with other partner communities so that such agreements compliment one another to achieve synergistic development across the communities.

(b) any existing community development agreements entered into by that partner community with other holders of mining rights so that its community development agreement compliments such existing agreements, and whether the mining right holder might become a party to any such existing agreements.

(c) any governmental community, local or regional development plans or schemes so that the agreement is 
in harmony with and compliments such plans or schemes.

\section{Recommended minimum expenditure}

8. - -

(1) It is recommended that the holder of a mining right who has entered into one or more community development agreements expend

(i) in the first calendar year following the commencement of mineral sales, no less than [ text ] percent ([ number ] \%) of the gross revenue amount earned pursuant to that right from mineral sales in the previous calendar year;

(ii) in the second calendar year following the commencement of mineral sales, no less than [ text ] percent ([ number ] \%) of the gross revenue amount earned pursuant to that right from mineral sales in the previous two calendar years divided by two (2);

(iii) in the third calendar year following the commencement of mineral sales and in each subsequent calendar year no less than [ text ] percent ([ number ] \%) of the gross revenue amount earned pursuant to that right from mineral sales in the previous three calendar years divided by three (3),

to implement all its agreement(s) or otherwise promote community development.

(2) Where a mining right holder makes expenditures pursuant to a community development agreement, it is recommended that such expenditures be done in a transparent, predictable and sustained manner over the life of the mine.

(3) The value of community development related work might include (whether incurred directly by the mining right holder or indirectly through payments by the mining right holder to a contractor, community trust, community foundation or other legal entity):

(i) work or funds irrevocably committed to fulfill any obligation of the mining right holder specified in a community development agreement;

(ii) salaries and benefits of any person responsible for managing the implementation of one or more 
community development agreements where such responsibilities comprise over fifty percent $(50 \%)$ of that person's time;

(iii) social baseline studies (the gathering and compilation of baseline data that describes the state of the ecological, social and economic environment and characteristics of the populations living in the area);

(iv) social impact and opportunities assessment work (assessment of the potential ecological, social and economic impacts of the project upon communities and measures to offset potential negative impacts and maximize positive impacts);

(v) competencies assessment (measuring and recording the skills in a community);

(vi) participatory planning (the preparation of development program plans where community members participate in the planning effort);

(vii) community and mining operation mapping (maps depicting what the community perceives as its community space, where mining operations will take place and when, where access is open, restricted, or closed);

(viii) institutional analysis processes (processes for identifying and discussing what institutions are present in and around a community);

(ix) problem census taking (processes by which community members articulate the problems they consider need addressing in their community);

(x) implementation of [Local Authority] regional and community development plans;

(xi) training programs for members of a partner community;

(xii) consultation processes between the mining right 
holder and a partner community or members of a partner community and or local government which are related to the creation or implementation of a community development agreement;

(xiii) community development agreement monitoring;

(xiv) conflict management activities (the implementation of a grievance process, other than Court actions, as stipulated in a community development agreement);

(xv) such other expenditures as may be appropriate in the circumstances.

\section{Transparency through reporting}

\section{9. - -}

(1) It is recommended that the holder of a mining right [ semiannually] provide to the [Mining Cadastre Office, Department of Mines, Ministry] for every community development agreement to which it is a party -

(a) a report substantially as set out in Schedule 1 \{Community Development Agreement Annual Report\} no later than [ date ], describing objectives, activities, milestones and results for January through December during the prior calendar year, and

(b) a report and attachments substantially as set out in Schedule 2 \{Community Development Annual Expenditure Report \} not later than [ date ] detailing its community development expenditures and total expenditure for January through December during the prior calendar year.

(2) It is recommended that the holder of a mining right providing the reports described in 9(1)(a) and 9(1)(b) of this guideline do so in [official language], but where a substantial proportion of the members of the Partner community which is party to the Community Development Agreement being reported on are not fluent in [official language] the mining right holder should consider submitting such reports in both [official language] and in the local language or dialect used by that community. 
Community

development agreements and periodic reports available to the public

Transfer

Preexisting mining rights
10. -

(1) All community development agreements, community development agreement [ semi-annual ] reports and community development annual expenditure reports (including all required attachments) submitted by past and present holders of a mining right in furtherance of these guidelines shall be open to free inspection by members of the public at the [Mining Cadastre Office, Department of Mines, Ministry] during normal Government office hours.

(2) It is recommended that a community development agreement, community development agreement [ semi-annual ] reports and community development annual expenditure reports (including all required attachments) submitted by the holder of a mining right in furtherance of these guidelines also be open to free inspection by any member of the partner community at the office of the mining right holder located closest to that community during normal office hours.

11. It is recommended that when a mining right is transferred to another party, the transferee should assume all rights and obligations of the transferor under any community development agreement relating to the mining right.

12. The holder of a mining right which came into force prior to the publication date of these guidelines should strive to have community development agreements with all partner communities within two years from the publication date of these guidelines. 


\section{SChedule 1. Community DeVelopment Agreement [SEMI-ANNUAL] RePOrt Form} (submit one report for each community development agreement)

1. Name of mining right holder:

2. Mining right registration number:

3. Year: Period being reported:

4. Name or description of partner community:

5. Year in which the community development agreement with the partner community came into effect:

6. Year in which the community development agreement was last amended and such amendment came into effect:

7. Attach an explanation addressing the following points:

○ description of the goals of the community development agreement;

○ description of the community development objectives and how they are to be met;

- community development agreement activities, milestones and results for the period being reported;

- development program plan activities, milestones, expenditures and results for the period being reported;

- description of community related challenges encountered, how these challenges are or may effect the project and community development, and how the challenges are or will be addressed;

- other information as may be requested in writing by the [Director of the Mining Cadastre, Director of Mines, Minister];

$\circ$ other information which the mining right holder wants to report; and

any such descriptions and information should be sufficiently detailed so that the reader thereof can determine whether the community development agreement is succeeding.

\section{Attestation of truth and accuracy}

This report has been prepared under my supervision. The report is truthful and substantially accurate in all its details.

Signature:

Name:

Email:

Telephone:

Fax:
Date:

Position:

Address: 


\section{SCHEDUle 2. COMMUNITY DEVELOPMENT EXPENDITURE ANNUAL REPORT FORM}

1. Name of mining right holder:

2. Mining right registration number:

3. Calendar year for which expenditures are being reported:

4. Year in which mineral sales were first earned under the mining right:

5. Calculate Gross Mineral Sales Revenues

If mineral sales first commenced in the preceding calendar year;

Sales: January 1 through December 31 of year preceding calendar year):

Gross Mineral Sales Revenue:

If mineral sales first commenced two years before this calendar year:

Sales:January 1 through December 31 of $1^{\text {st }}$ year preceding this year:

+ Sales:January 1 through December 31 of $2^{\text {nd }}$ year preceding this year)

total:

Gross Mineral Sales Revenue:

divide total by 2

If mineral sales first commenced three years or more before this calendar year:

Sales: January 1 through December 31 of $1^{\text {st }}$ year preceding this year:

+ Sales: January 1 through December 31 of $2^{\text {nd }}$ year preceding this year:

+ Sales: January 1 through December 31 of $3^{\text {rd }}$ year preceding this year:

total::

divide total by 3

Gross Mineral Sales Revenue:

6. Calculate the recommended community development expenditure for last calendar year

Gross Mineral Sales Revenues from $\{5\}$

Recommended Community Development Annual Expenditure:

$\underline{x}[? \%]$

7. Calculate actual community development expenditure for last calendar year (the following table can be used as an aid in the calculation)

Notes:

Expenditures reported here include those incurred directly by the mining right holder or indirectly through payments by the mining right holder to a contractor, community trust, community foundation or other legal entity for the listed item. 


\begin{tabular}{|c|c|}
\hline Type of Expenditure & $\begin{array}{l}\text { Expenditure } \\
\text { Amount }\end{array}$ \\
\hline $\begin{array}{l}\text { a. work or funds irrevocably committed to fulfill any obligation of the } \\
\text { mining right holder specified in a community development agreement } \\
\text { (attachment(s): for every community development agreement attach a } \\
\text { detailed list of expenditures made with regard to that agreement, sum } \\
\text { the expenditures for each agreement, and enter the total of those sums } \\
\text { here) }\end{array}$ & \\
\hline $\begin{array}{l}\text { b. salaries and benefits of any person responsible for managing the } \\
\text { implementation of one or more community development agreements where } \\
\text { such responsibilities comprise over fifty percent (50\%) of that person's time }\end{array}$ & \\
\hline $\begin{array}{l}\text { c. social baseline studies (the gathering and compilation of baseline data } \\
\text { that describes the state of the ecological, social and economic environment } \\
\text { and characteristics of the populations living in the area) }\end{array}$ & \\
\hline $\begin{array}{l}\text { d. social impact and opportunities assessment work (assessment of the } \\
\text { potential ecological, social and economic impacts of the project upon } \\
\text { communities and measures to offset potential negative impacts and maximize } \\
\text { positive impacts) }\end{array}$ & \\
\hline $\begin{array}{l}\text { e. competencies assessment (measuring and recording the skills in a } \\
\text { community) }\end{array}$ & \\
\hline $\begin{array}{l}\text { f. participatory planning (the preparation of development program plans } \\
\text { where community members participate in the planning effort) }\end{array}$ & \\
\hline $\begin{array}{l}\text { g. community and mining operation mapping (maps depicting what the } \\
\text { community perceives as its community space, where mining operations will } \\
\text { take place and when, where access is open, restricted, or closed) }\end{array}$ & \\
\hline $\begin{array}{l}\text { h. institutional analysis processes (processes for identifying and discussing } \\
\text { what institutions are present in and around a community) }\end{array}$ & \\
\hline $\begin{array}{l}\text { i. problem census taking (processes by which community members } \\
\text { articulate the problems they consider need addressing in their community) }\end{array}$ & \\
\hline $\begin{array}{l}\text { j. implementation of [Local Authority] regional and community } \\
\text { development program plans }\end{array}$ & \\
\hline $\begin{array}{l}\text { k. training programs for members of a partner communities (if not included } \\
\text { in }\{a\} \text { ) }\end{array}$ & \\
\hline $\begin{array}{l}\text { 1. consultation processes between the mining right holder and a partner } \\
\text { community or members of a partner community and or local government } \\
\text { which are related to the creation or implementation of a community } \\
\text { development agreement }\end{array}$ & \\
\hline m. community development agreement monitoring; & \\
\hline $\begin{array}{l}\text { n. conflict management activities (the implementation of a grievance } \\
\text { process, other than court actions, as stipulated in a community development } \\
\text { agreement) }\end{array}$ & \\
\hline o. other expenditures & \\
\hline p. subtotal $\{$ a through $o\}:$ & \\
\hline $\begin{array}{l}\text { q. to a total of not more than }[\text { text }] \text { percent }([\text { number }] \%) \text { of subtotal }\{\mathrm{p}\} \text {, } \\
\text { administrative expenses. }\end{array}$ & \\
\hline
\end{tabular}


Community Development Agreement Model Regulations and Example Guidelines

Prepared for the World Bank by James Otto

Total Community Development Expenditure in [year]

\section{Attestation of truth and accuracy}

This report has been prepared under my supervision. The report is truthful and substantially accurate in all its details, and documentation is available to verify all expenditures.

Signature:

Date:

Name:

Position:

Email:

Telephone:

Fax:

Address: 


\section{Annex 4. Phase 1 Consultation (Meetings and Persons Met)}

\section{Meetings in Washington DC}

Tuesday - May 19, 2009

Boubacar Bocoum, Senior Mining Specialist, COCPO, World Bank

Craig Andrews, Senior Mining Specialist, COCPO, World Bank

Deval Desia (visiting student researching community development agreements)

John Strongman, Short Term Consultant, COCPO, World Bank

Dafna Tapiero, Manager, Community Development, IFC

Robin Weismann, Senior Investment Officer, Corporate Advice Department, IFC

Wenlei Zhou, Social Development Specialist, Environment and Social, IFC

Daniel Owen, Coordinator, Community-Driven Development, CDD \& Local Governance, Social Development, World Bank

Wednesday May 20

Graham Hancock, Senior Mining Specialist, COCPO, World Bank

Boubacar Bocoum, Senior Mining Specialist, COCPO, World Bank

COCPO Group meeting including: Boubacar Bocoum, Adriana Eftimie, Bryan Land, Gary McMahon, Remi Pelon, Chris Sheldon, Kristina Svensson, Andre Ufer

Bryan Land, COCPO, World Bank

Thursday May 21

Adriana Eftimie, Mining Specialist, COCPO, World Bank

Remi Pelon, Mining Specialist, COCPO, World Bank

Peter Adler, President and Chief Executive Officer, Keystone Center

Paolo Desa, Sector Manager, COCPO, World Bank

Boubacar Bocoum, Senior Mining Specialist, COCPO, World Bank

Kristina Svensson, Operations Officer, COCPO, World Bank 
Community Development Agreement Model Regulations and Example Guidelines

Prepared for the World Bank by James Otto

Friday May 22

Corinna Gilfillan, Head of US Office, Global Witness

Dana Wilkins, Policy Assistant, Global Witness

Sarah Pray, Coordinator, Publish What You Pay

John Groom, Chairman ICMM Working Group (conference call)

Boubacar Bocoum, Senior Mining Specialist, COCPO, World Bank

Kristina Svensson, Operations Officer, COCPO, World Bank

Paolo Desa, Sector Manager, COCPO, World Bank

Boubacar Bocoum, Senior Mining Specialist, COCPO, World Bank

Kristina Svensson, Operations Officer, COCPO, World Bank

\section{Meetings in Boulder, Colorado to Obtain Sample Agreements / Best Practice Advice}

David A. Baker, Vice President, ESR, Chief Sustainability Officer, Newmont Mining Corporation

Chris Baldwin, Partner, Lawson Lundell (counsel for Canadian CDA agreements)

Patrick Garver, Counsel, Barrick Gold Corporation

Susan Joyce, Principal, On Common Ground (by phone) 


\section{AnNex 5. TeChNiCAL RevieW Workshop AtTENDEeS}

(WORKSHOP ON 1 OCTOBER 2009)

\section{Civil Society}

Todd Bryan, Senior Associate, Keystone Center

Myriam Cabrera, On Common Ground

\section{Facilitator}

James Otto, Consultant

\section{Industry}

Aidan Davy, ICMM

Peter Sinclaire, Senior Director, Corporate Social Responsibility, Barrick Gold Corporation

Cassie Boggs, Senior Vice President, Barrick Gold Corporation

\section{World Bank Group}

Arjun Ballah, Community Development, IFC

Allison Berg, COCPO, World Bank

Boubacar Bocoum, Senior Mining Specialist, COCPO, World Bank

Paolo de Sa, Sector Manager, COCPO, World Bank

Charles Di Leva, LEGEN, World Bank

Veronica Kohler, CASM / World Bank

Bryan Land, COCPO, World Bank

Gary McMahon, Senior Mining Specialist, COCPO, World Bank

Sachiko Morita, LEGEN, World Bank

Remi Pelon, COCPO, World Bank

Christopher Sheldon, COCPO, World Bank

Kristina Svensson, Operations Officer, COCPO, World Bank

Dafna Tapiero, Manager, Community Development, IFC

Gotthard Walser, CASM / World Bank

Warren Waters, Africa Safeguard Coordinator 


\title{
Annex 6. Consultant's Terms of Reference
}

\author{
PHASE 1 \\ TERMS OF REFERENCE
}

\section{BACKGROUND}

Although developing nations are each unique in their challenges, opportunities and capacities those that have significant natural resources endowments may be able to use similar tools to realize common objectives. Over the past decade there has been an emphasis, by much of the donor and multilateral community, to emphasize country specific projects. In some instances this has led to a duplication of efforts where a common approach could have served multiple countries.

One such example where a common approach might be adopted by a number of countries is related to the sustained development of communities that are impacted by extractive industries projects. Often such communities bear the brunt of negative impacts but realize little development benefit, or where benefits are realized, these benefits may not be sustainable once the extractive industry has closed. Approaches that aim to achieve sustainable community development would be of interest to many nations.

Communities often expect that when an extractive project opens, the community will receive benefits. Traditionally, such benefits were received in two primary forms:

- paternalistic contributions, monetary and otherwise, from the company extracting the resource as part of its social corporate responsibility program;

o investment from or sharing in fiscal tax revenues through the government's general budgeting process, or more recently in some countries, through an earmarked portion of taxes statutorily mandated for affected communities.

Both of these forms of community development assistance have their merits and demerits and are not mutually exclusive.

Another possible modality for community development assistance is some form of community development agreement. Some companies have experimented with such "contracts with the community" as part of their social corporate responsibility risk management programs. Presently, though not always, these agreements tend to be non-legal in nature and are viewed by companies as a voluntary means by which to help manage community expectations.

Examples of extractive of projects being blocked or impeded by local communities are on the rise. Aside from an awareness that impeded projects may have a detrimental impact on fiscal revenues, governments are also interested in seeing how companies can further local level development. Community development agreements today tend to be voluntary and nonlegally binding (soft law). However, that need not be the case, and requirements and general content of such agreements can be mandated by law. In nations where extractive projects 
operate under ad hoc negotiated agreements, requirements for integral or independent community development agreements can also be stipulated.

\section{OBJECTIVES AND DELIVERABLES}

This assignment will build on previously completed work, including the drafting of the Community Development Agreement model regulation. The objective of this assignment is to consult broadly and gain feedback on this DRAFT from civil society and private firms, incorporate this feedback into the draft regulations and guidelines. Deliverables: Draft Community Development Agreement regulations and guidelines.

\section{SCOPE OF WORK}

Community Development Model Regulation Review, Washington, DC, October 1, 2009. The Consultant will prepare material and a presentation, and participate in the preparation of a one-day workshop/review meeting with representatives from the World Bank, civil society, and private mining firms. The meetings will be arranged by the Oil, Gas and Mining Policy Division, COCPO. Preparation 1 day, meeting with travel 3 days, follow-up work 1 day. Total 5 days.

\section{Deliverable}

The Consultant will deliver revised draft regulations and guidelines to the World Bank before November 15, 2010.

PHASE 2

\section{TERMS OF REFERENCE}

\section{BACKGROUND}

(See Phase 1 Background section)

\section{OBJECTIVES AND DELIVERABLES}

Objectives: This assignment will build on previously completed work, including the drafting of the Community Development Agreement model regulation. The objective of this assignment is to continue broad consultations on the draft model regulations, gain feedback from civil society, mining companies, and Governments, and revise draft regulations accordingly.

Consultations will include sharing with private sector firms at PDAC in Toronto in March, 2010, and consult on draft regulations at Rocky Mountain Mineral Law Institute in Banff, Canada. It would also include a final consultation in Washington DC in June 2010. The consultant will also incorporate information from another study looking at the practical 
application of CDAs, and hold discussions with these consultants on the main building blocks of the Draft regulations.

Deliverables:

- Final Community Development Agreement regulations and guidelines.

- Presentation for PDAC

- Presentation for Banff

- Presentation for joint final consultations

\section{SCOPE OF WORK}

The consultant will do the following additional tasks:

- Prepare and lead discussions with private sector firms and governments during PDAC in Toronto in March, 2010 (4 days).

- Joint final presentation to various stakeholders (4 days)

- Present and participate in Banff conference.

- Discuss and advise consultants doing the practical research on CDAs (3 days, home base)

- Revise Draft regulations (3 days)

REPORTING

Consultant will report to Boubacar Bocoum, Senior Mining Specialist (COCPO)

\section{DeliVerables, Timing, AND DURATION}

The contract will deliver presentations for civil society organizations, presentation for PDAC, presentation for joint consultations, and finally the revised draft regulations and guidelines to the World Bank before June 15, 2010. 


\title{
Annex 7. About the Consultant
}

Professor James Otto (retired) holds degrees in law, mineral economics and engineering. He has worked for multilateral agencies, governments and mining companies in over fifty nations on matters relating to mining policy, laws and taxation. His accomplishments include leading or participating with teams to write mining laws and/or designing fiscal systems in over twenty nations. His books and studies on mining policies, laws, regulation and taxation have become standard references for many governments and companies. He is co-author of The Regulation of Mineral Enterprises: A Global Perspective on Economics, Law and Policy (RMMLF, 2002), editor and co-author of The Taxation of Mineral Enterprises (Graham and Trotman/Kluwer, 1995), and co-author of Global Mining Taxation Comparative Study (Colorado School of Mines, 1996, 2000). His latest co-authored book, Mining Royalties, was published by the World Bank in 2006. He has published two edited books with the United Nations on sustainable development and mining. He has edited/co-authored three books on Asia/Pacific mineral sector regulation, investment and taxation: Mining Legislative Frameworks in Asian Countries (Mining Journal Books Ltd. in conjunction with the United Nations Revolving Fund, 1998), Minerals Industry Taxation Policies for Asia and the Pacific (United Nations ESCAP, 1992), and Mineral Investment Conditions in Selected Countries of the Asia-Pacific Region (United Nations ESCAP, 1992). Professor Otto was formerly United Nations Chief Technical Advisor (UNDTCD), Assistant Director and Riotinto Senior Lecturer at the Centre for Petroleum and Mineral Law and Policy at the University of Dundee (the largest natural resources law program in Europe), Director of the Institute for Global Resources Policy and Management at the Colorado School of Mines, and Director of the Environmental and Natural Resources Law Graduate Studies Program at the University of Denver Sturm College of Law (the largest natural resources law program in North America).

\author{
James Otto \\ Attorney and Mineral Economist \\ 1344 Scrub Oak Circle \\ Boulder, Colorado 80305, USA \\ jim.otto@comcast.net \\ www.ottomininglaw.com \\ phone: 1-303-494-8241; fax: 1-303-554-0227
}


Community Development Agreement Model Regulations and Example Guidelines Prepared for the World Bank by James Otto

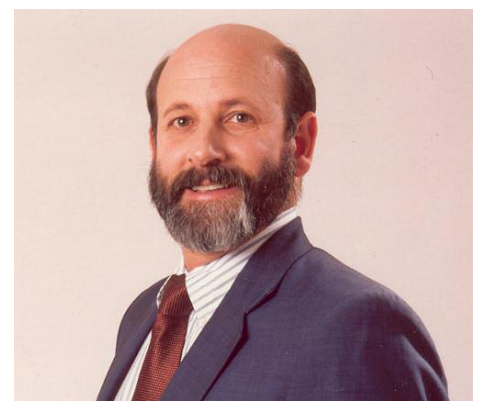

